\title{
Identifying and explaining the farming system composition of agricultural landscapes: The role of socioeconomic drivers under strong biophysical gradients
}

\author{
J.F. Silva ${ }^{\mathrm{a}, *}$, J.L. Santos ${ }^{\mathrm{b}}$, P.F. Ribeiro ${ }^{\mathrm{b}}$, M.J. Canadas ${ }^{\mathrm{b}}$, A. Novais ${ }^{\mathrm{b}}$, A. Lomba ${ }^{\mathrm{c}}$, M.R. Magalhães ${ }^{\mathrm{a}}$, \\ F. Moreira ${ }^{\mathrm{c}, \mathrm{d}}$ \\ ${ }^{a}$ LEAF, Linking Landscape, Environment, Agriculture and Food Research Centre, Instituto Superior de Agronomia, Universidade de Lisboa, $1349-017$ Lisboa, Portugal \\ ${ }^{\mathrm{b}}$ Centro de Estudos Florestais, Instituto Superior de Agronomia, Universidade de Lisboa, Portugal \\ ${ }^{\mathrm{c}}$ CIBIO/InBio, Centro de Investigação em Biodiversidade e Recursos Genéticos, Universidade do Porto, Campus Agrário de Vairão, Vairão, Portugal \\ ${ }^{\mathrm{d}}$ CEABN/InBio, Centro de Ecologia Aplicada "Professor Baeta Neves", Instituto Superior de Agronomia, Universidade de Lisboa, Tapada da Ajuda, 1349-017 Lisboa, \\ Portugal
}

\section{A B S T R A C T}

In mountain landscapes, agricultural abandonment is taking place in the most vulnerable areas, while intensification increases in the most productive lands. These contrasting processes, which have different impacts on biodiversity and ecosystem services (BES), are related to changes in the farming system component of these landscapes.

Farming systems are identified based on farmer's decisions on, for example, type of crop and level of fertilizers, which represent the descriptors of farming systems and can be grouped into several dimensions (e.g. land use and intensity). Since obtaining this data at farm-level is often difficult, an alternative is to study the spatial combinations of farming systems at parish-level, i.e., Farming System Mixes (FSM), relying on agricultural census data.

Other biophysical (e.g. climate, soil) and socioeconomic (e.g. labour, farmer's age) variables, independent of farmers' decisions, represent the exogenous drivers of these decisions. The separation between descriptors and drivers is important to improve knowledge about what drives farmers' decisions regarding farming system choice, as these choices are often the focus of policies aiming the support of BES.

In this study, we explored the underlying drivers of FSM and assessed the role of socioeconomic drivers, main target for policy makers, in a context of strong biophysical gradients. Biophysical drivers emerge as those that primarily discriminate between the FSM located in different topographic positions (valleys, mountains and plateau). In the situations where there is a greater range of productive choices available for farmers, such as in valleys, socioeconomic drivers assume a preponderant role on farming system choice.

\section{Introduction}

Covering nearly half of the European continental area, mountain landscapes support biological and cultural diversity, while providing a wide range of ecosystem services (Hopkins, 2011). Constantly changing, these landscapes are following two contrasting processes. On the one hand, agricultural abandonment (MacDonald et al., 2000) and, on the other, intensification of the most productive agricultural land (Stoate et al., 2009), with different impacts on biodiversity and ecosystem services (BES), on and off farmland (Hird, 2017).

Farmland abandonment is associated with increased risk of fire due to the increased accumulation of fuel in the landscape (Lomba et al., 2020; Moreira, Rego, \& Ferreira, 2001). On the other hand, it allows the rewilding of abandoned areas generating several benefits through the provisioning of ecosystem services such as freshwater, air quality, wildlife support, carbon storage capacity or recreation/tourism (Pereira \& Navarro, 2015). Contrastingly, while supporting high yields, intensification of agricultural land depends on chemical and mechanical inputs known to have adverse effects on the environment (Stoate et al., 2001). Still, some degree of intensity in mountainous agricultural areas is essential for the conservation of the heritage incorporated in the structure and composition of these cultural landscapes (van der Zanden, 2016), which can play an important role in the conservation of farmland biodiversity (Bignal \& McCracken, 2000; Lomba et al., 2020). Both processes are linked with spatial and temporal changes in the most dynamic component of agricultural landscapes - the farming systems (Andersen, 2017).

A farming system can be defined as a particular way of combining

\footnotetext{
* Corresponding author at: Instituto Superior de Agronomia, Tapada da Ajuda, 1349-018 Lisboa, Portugal.

E-mail addresses: joaofsilva@isa.ulisboa.pt (J.F. Silva), jlsantos@isa.ulisboa.pt (J.L. Santos), pfribeiro@isa.ulisboa.pt (P.F. Ribeiro),

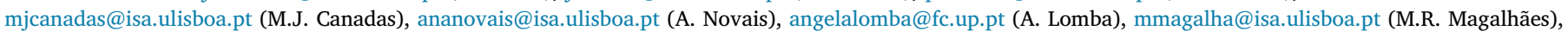
fmoreira@isa.ulisboa.pt (F. Moreira).
} 


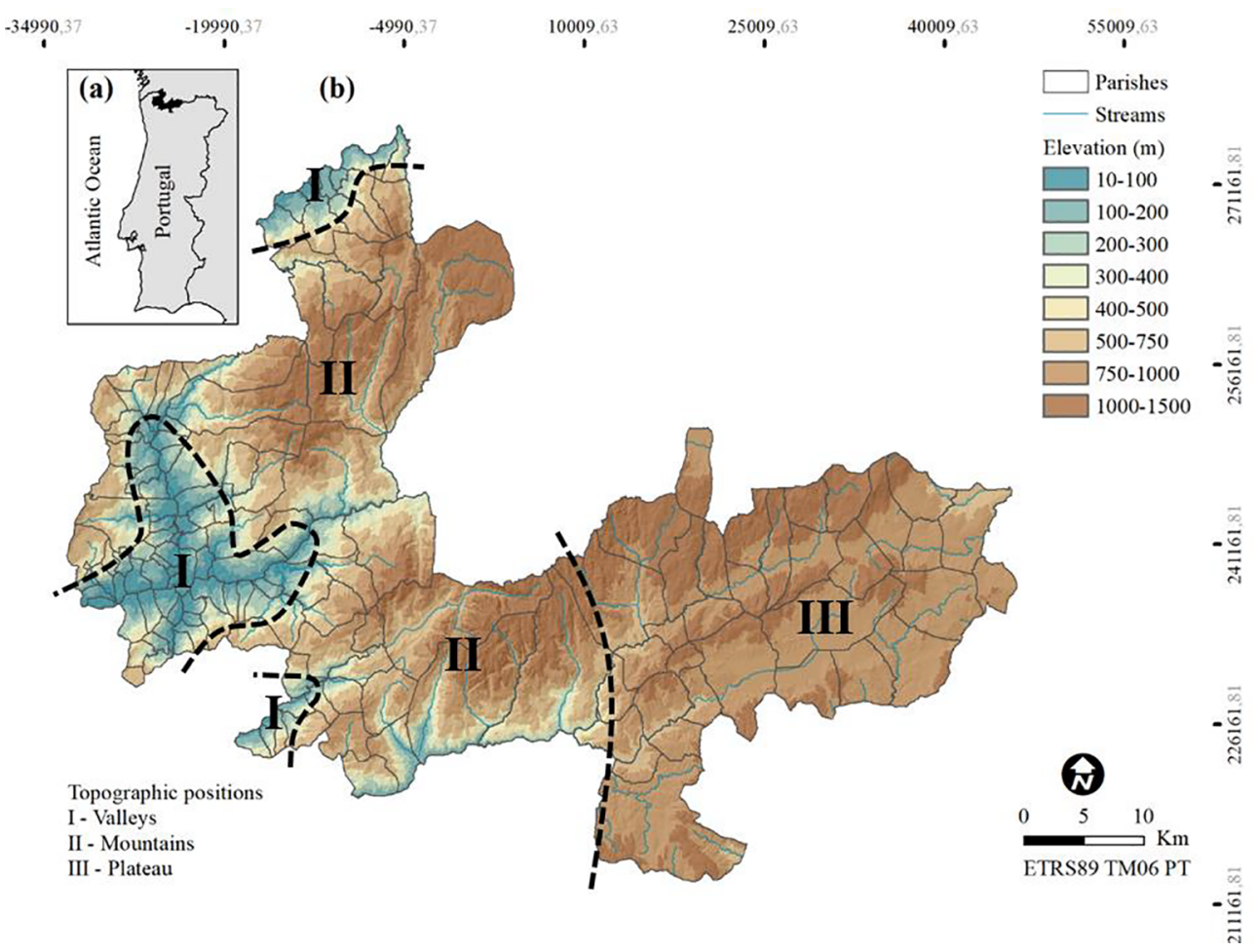

Fig. 1. Location of the study area in Portugal (a) and a zoom (b) focusing on the elevation range, streams and a conceptual delineation of the different topographic positions: valleys (I), Peneda-Gerês Mountains (II) and Barroso plateau (III).

production factors (land, labour, tools and other inputs) in order to obtain plant and/or animal production that is shared by a set of farms (Reboul, 1976). Farming systems are identified based on descriptors such as type of crops and level of fertilizers, which depend on farmers' decisions. These descriptors can be grouped into several dimensions, such as land use and intensity. Other biophysical (e.g. climate, soil) and socioeconomic (e.g. farmer's age and education, labour) variables, often independent of the farmer's decisions, are taken as exogenous drivers of these decisions.

Farming systems research is ideally based on farm-level data regarding the descriptors, which is often lacking or difficult to access. To overcome this limitation, an alternative is to use data from agricultural census, usually available at distinct administrative levels (e.g. parishes) and considered as land management units (Rizzo et al., 2013). The farming system choices made by a set of farmers within a parish thus represent a spatial combination of different farming systems, or a Farming System Mix (FSM). For a given parish, the FSM can be characterized by descriptors, grouped in several dimensions: farmland share (share of utilised agricultural area), average intensity (e.g. per hectare output), livestock composition (e.g. share of cattle in total livestock), agricultural land use (e.g. share of arable land) and farm-level specialization pattern (e.g. share of farms specialized in wine).

Being a combination of different farming systems, FSM are driven by the same type of biophysical and socioeconomic drivers as individual farming systems. For example, slope influences crop choice and yields (Bhatta \& Doppler, 2011), farmer's age and education affect farm-level management choices (Jel, Carillo, Carillo, Venittelli, \& Zazzaro, 2013; Prokopy, Floress, Klotthor-Weinkauf, \& Baumgart-Getz, 2008), and population density is related to grassland management intensity (Hinojosa et al., 2019).

In the field of land-use planning and management, some studies focused only on the biophysical environment by assessing crop suitability (e.g. Elsheikh et al., 2013; Kamkar et al., 2014; Kilic et al., 2005). However, taking into account the role of socioeconomic drivers and, therefore, fully addressing all relevant drivers of choice, increases the likelihood of plans to have a successful implementation (Budiharta, Meijaard, Wells, Abram, \& Wilson, 2016). For example, we can select the best soil and slope for a specific crop, but if the system is highly dependent on external labour whose supply is insufficient, production may become unfeasible.

In this study, we aimed at: i) exploring the underlying drivers of change of the farming system component of agricultural landscapes by clearly separating the descriptors from the drivers of FSM; ii) assessing the role of socioeconomic drivers of farming system choice when biophysical gradients are strong, for which we selected a mountain area of Northern Portugal as our study area.

We hypothesized that, when biophysical constraints are stronger, the range of observed farming systems is narrower and less room is left for socioeconomic drivers to influence farming system choice, while, when the biophysical environment allows for a broader range of farming system options, the role of socioeconomic drivers is given a greater expression. To test this hypothesis, we have fitted two different explanatory models, one based on biophysical drivers alone (Biophysical Model) and another including both socioeconomic and biophysical drivers (Complete Model). We also subdivided the study area into several topographic positions (valleys, mountains and plateau) that show variations in biophysical constraints to farming.

Our premises were 1) that a greater diversity of FSM will occur in the topographic positions with less biophysical constraints; 2) and that the biophysical drivers alone are not enough to discriminate between these FSM and only the Complete model allows us to predict the observed FSM at a single point in time (cross-section data). The comparison between both models allows us to quantify the added value of socioeconomic drivers in the discrimination of the FSM and, by establishing a relationship with the topography, it allows us to analyse whether more biophysical constrains imply a reduction in the number of possible choices for farmers and, thus, less opportunities for achieving BES goals through policies aimed at manipulating the socioeconomic drivers of farming system choice (Ribeiro et al., 2018). 


\section{Methods}

\subsection{Study area}

The study area is located in a mountainous region of Northern Portugal (Fig. 1a), between latitude $42^{\circ} 15^{\prime} \mathrm{N}$ and $41^{\circ} 58^{\prime} \mathrm{N}$ and longitude $8^{\circ} 53^{\prime} \mathrm{W}$ and $7^{\circ} 57^{\prime} \mathrm{W}$. It covers approximately 195,087 ha comprising five municipalities (Melgaço, Arcos de Valdevez, Ponte da Barca, Terras de Bouro and Montalegre) and 146 parishes (Fig. 1b). To the North, it shares the border with the region of Galicia, Spain. Traditionally, agriculture, including food crops and extensive grazing, was the main economic activity, but the region is undergoing significant changes due to farmland abandonment. At present, the main regional income sources are services, including tourism. However, agriculture still maintains a marked presence in rural areas, even if indirect, since at least one member of many households owns a farm (Baptista, 2010).

Topographically, the western section of the study area mostly consists of lowlands, characterized by gently sloping valleys (Fig. 1b.I) with deep soils. The altitude gradually increases to the central section, where the steep Peneda-Gerês Mountains, punctually interrupted by narrow and deep valleys, are located (Fig. 1b.II). In the eastern section, at an altitude of more than $750 \mathrm{~m}$, lies the Barroso plateau (Fig. 1b.III), where the slopes are again gentler than on the adjacent mountains. The elevation range (Fig. 1b) and the increasing distance to the Atlantic Ocean to the East give rise to great climatic variation within a relatively small area. In the valleys near the sea, the temperature is higher, and the precipitation is lower than in the mountains. The Barroso Plateau, affected by continentality, altitude and in the rain shadow area of the Peneda-Gerês Mountains, presents lower temperature and lower precipitation levels, as well as greater thermal amplitudes.

In the current context, the valleys are characterized by less biophysical constraints to the practice of agriculture than the mountains and the plateau. In the mountains, steep slopes impose restrictions on mechanization and hinder the expansion of the utilized agricultural area. The climatic conditions that characterize the plateau do not allow the development of certain crops more susceptible to frost such as maize or vineyards.

About half of the study area (ca. 51.2\%) is utilized agriculture area (UAA), of which $89.7 \%$ are permanent pastures, most of them $(81.3 \%)$ located in common land. Temporary crops occupy $8.1 \%$ and permanent crops, dominated by vineyards, $1.9 \%$ of the UAA. Livestock is largely dominated by bovine $(68.2 \%$ of standard livestock units), followed by equine (14.3\%), sheep (10\%) and goats (7.5\%).

\subsection{Data analysis}

\subsubsection{Farming systems Mix typology}

Agricultural information at the parish level was obtained from the latest (2009) Agricultural Census (INE, 2011b). We excluded one of the 146 parishes of the study area (São Salvador) due to lack of agricultural data. The remining 145 parishes was then classified as a Farming System Mix (FSM), derived from 26 variables that represent farmers' individual choices, i.e. descriptors of farming systems. These descriptors were organized into five dimensions: farmland share, agricultural intensity, livestock composition, agricultural land use, and farm specialization pattern (Table 1).

Multivariate statistical methods have been widely used for building farming system typologies (Alvarez, Paas, Descheemaeker, Tittonell, \& Groot, 2014; Köbrich, Rehman, \& Khan, 2003). The farming system typology was carried by using two methods: principal component analysis (PCA) and cluster analysis. PCA was performed on a correlation matrix of 26 variables (Table 1 ) to reduce variable redundancy. Following Kaiser's rule (Kaiser, 1960), we selected the principal components with eigenvalues greater than one (Appendix A). A hierarchical cluster analysis was then performed on the principal components identified in the PCA using the Ward's method (Mądry, Roszkowska-
Table 1

Summary statistics of variables used to derive the typology of the farmingsystem mixes in the study area. UAA = Utilized Agricultural Area. $\mathrm{LU}=$ livestock units. Total grazing $\mathrm{LU}=$ cattle + sheep + goats + equine .

\begin{tabular}{|c|c|c|c|c|}
\hline Description & Mean & SD & Min & Max \\
\hline \multicolumn{5}{|l|}{ Farmland share } \\
\hline \multicolumn{4}{|l|}{ Agricultural intensity } & 0.446 \\
\hline $\begin{array}{l}\text { Average standard output }(€) \text { per hectare of total } \\
\text { land }\end{array}$ & 268.7 & 210.2 & 24.8 & 1319.6 \\
\hline Share of irrigable area in total land area & 0.110 & 0.081 & 0.001 & 0.409 \\
\hline $\begin{array}{l}\text { Average grazing LU per hectare of total land } \\
\text { Livestock composition }\end{array}$ & 0.132 & 0.088 & 0.006 & 0.596 \\
\hline Share of cattle in total grazing LU & 0.593 & 0.233 & 0.000 & 0.974 \\
\hline Share of sheep in total grazing LU & 0.177 & 0.167 & 0.000 & 0.802 \\
\hline Share of goats in total grazing LU & 0.095 & 0.123 & 0.000 & 0.613 \\
\hline \multicolumn{5}{|l|}{ Agricultural land use (shares in total land area) } \\
\hline Share of arable land & 0.066 & 0.054 & 0.001 & 0.241 \\
\hline Share of permanent pastures in commons & 0.238 & 0.295 & 0.000 & 1.000 \\
\hline $\begin{array}{l}\text { Share of permanent pastures in private land } \\
\text { (lameiros) }\end{array}$ & 0.072 & 0.079 & 0.000 & 0.381 \\
\hline Share of permanent crops & 0.026 & 0.044 & 0.000 & 0.272 \\
\hline Share of kitchen garden & 0.003 & 0.003 & 0.000 & 0.019 \\
\hline Share of fallow land & 0.003 & 0.007 & 0.000 & 0.044 \\
\hline Share of rye & 0.005 & 0.012 & 0.000 & 0.074 \\
\hline Share of maize & 0.023 & 0.019 & 0.000 & 0.095 \\
\hline Share of potato & 0.004 & 0.005 & 0.000 & 0.022 \\
\hline Share of annual fodder crops & 0.033 & 0.035 & 0.000 & 0.179 \\
\hline \multicolumn{5}{|l|}{ Farm specialization pattern } \\
\hline $\begin{array}{l}\text { Share of private UAA used by farms specialized } \\
\text { in field crops }\end{array}$ & 0.068 & 0.090 & 0.000 & 0.366 \\
\hline $\begin{array}{l}\text { Share of private UAA used by farms specialized } \\
\text { in wine }\end{array}$ & 0.081 & 0.168 & 0.000 & 0.802 \\
\hline $\begin{array}{l}\text { Share of private UAA used by farms specialized } \\
\text { in cattle }\end{array}$ & 0.230 & 0.232 & 0.000 & 0.827 \\
\hline $\begin{array}{l}\text { Share of private UAA used by farms specialized } \\
\text { in sheep }\end{array}$ & 0.039 & 0.061 & 0.000 & 0.318 \\
\hline $\begin{array}{l}\text { Share of private UAA used by farms specialized } \\
\text { in goats }\end{array}$ & 0.204 & 0.150 & 0.000 & 0.758 \\
\hline $\begin{array}{l}\text { Share of private UAA used by mixed livestock } \\
\text { farms }\end{array}$ & 0.027 & 0.067 & 0.000 & 0.605 \\
\hline $\begin{array}{l}\text { Share of private UAA used by farms combining } \\
\text { annual and permanent crops }\end{array}$ & 0.067 & 0.093 & 0.000 & 0.533 \\
\hline $\begin{array}{l}\text { Share of private UAA used by mixed livestock } \\
\text { farms, mainly granivores and grazing } \\
\text { livestock }\end{array}$ & 0.057 & 0.093 & 0.000 & 0.452 \\
\hline $\begin{array}{l}\text { Share of private UAA used by farms combining } \\
\text { permanent/various crops and livestock }\end{array}$ & 0.178 & 0.178 & 0.000 & 0.820 \\
\hline
\end{tabular}

Mądra, Gozdowski, \& Hryniewski, 2016). The hierarchical clustering outcome was assessed based on the resulting dendrogram (Ribeiro et al., 2014), and a map of the clusters was developed in GIS for a better understanding of the spatial distribution of the FSM types. The main topographic positions in the study area (valleys, mountains and plateau) were also mapped in order to investigate possible relationships between these positions and FSM.

\subsubsection{Discrimination of farming systems mixes}

To investigate the discrimination of Farming Systems Mixes (FMS) we gathered parish-level information on 23 biophysical (Table 2) and 29 socioeconomic (Table 3) variables. These variables, independent of farmers' decisions, were selected as potentially influencing their choices, thus representing potential drivers of farming systems.

Regarding biophysical data, we derived terrain attributes (i.e. slope and aspect) from a $25 \mathrm{~m}$ digital elevation model (DEM) (INAG, 2010) in a GIS. Information on soil depth, texture and $\mathrm{pH}$, three characteristics that greatly define agricultural possibilities and constraints, originates from the soil map. The study area covers two different soil surveys (Entre-Douro \& Minho (Agroconsultores, \& Geometral, 1995) and Northeast region (Agroconsultores, \& Coba, 1991), both published at the $1 / 100000$ scale. Climate data, with a spatial resolution of $30 \mathrm{~s}(\sim 1$ $\mathrm{km}^{2}$ ), originates from WorldClim 2.0 (Fick \& Hijmans, 2017). 
Table 2

Summary statistics of biophysical variables used in the discrimination of the farming-system mix.

\begin{tabular}{|c|c|c|c|c|}
\hline Description & Mean & SD & Min & Max \\
\hline Elevation range (difference between the highest and the lowest point of the parish) (m) & 563 & 289 & 71 & 1371 \\
\hline Share of total land area with slopes between 0 and $12 \%$ & 0.203 & 0.145 & 0.030 & 0.590 \\
\hline Share of total land area with slopes between 12 and $25 \%$ & 0.332 & 0.082 & 0.150 & 0.510 \\
\hline Share of total land area with slopes greater than $25 \%$ & 0.466 & 0.199 & 0.060 & 0.820 \\
\hline Share of total land area with flat slope & 0.000 & 0.001 & 0.000 & 0.010 \\
\hline Share of total land area with North facing slopes & 0.233 & 0.147 & 0.020 & 0.680 \\
\hline Share of total land area with East facing slopes & 0.248 & 0.153 & 0.000 & 0.700 \\
\hline Share of total land area with South facing slope & 0.230 & 0.147 & 0.010 & 0.610 \\
\hline Share of total land area with West facing slopes & 0.287 & 0.151 & 0.030 & 0.710 \\
\hline Share of total land area with soil depth between 0 and $25 \mathrm{~cm}$ & 0.044 & 0.142 & 0.000 & 0.920 \\
\hline Share of total land area with soil depth between 25 and $50 \mathrm{~cm}$ & 0.623 & 0.249 & 0.000 & 1.000 \\
\hline Share of total land area with soil depth greater than $50 \mathrm{~cm}$ & 0.333 & 0.262 & 0.000 & 1.000 \\
\hline Share of total land area with medium soil texture & 0.009 & 0.003 & 0.000 & 0.010 \\
\hline Share of total land area with coarse soil texture & 0.912 & 0.205 & 0.030 & 1.000 \\
\hline Share of total land area with soil $\mathrm{pH} 0-5$ & 0.816 & 0.267 & 0.000 & 1.000 \\
\hline Share of total land area with soil $\mathrm{pH} 5-6$ & 0.184 & 0.266 & 0.000 & 1.000 \\
\hline Share of total land area with soil $\mathrm{pH} 6-7$ & 0.000 & 0.004 & 0.000 & 0.040 \\
\hline Average annual precipitation & 1411 & 84 & 1233 & 1584 \\
\hline Average minimum temperature of the coldest month & 1.3 & 1.5 & -1.8 & 3.3 \\
\hline Average maximum temperature of the warmest month & 23.2 & 1.5 & 19.7 & 25.4 \\
\hline Average annual temperature & 12.7 & 1.5 & 9.5 & 14.6 \\
\hline Average annual thermal amplitude & 21.8 & 1.0 & 19.4 & 24.7 \\
\hline Maximum average annual temperature within the parish & 13.7 & 1.3 & 10.4 & 14.7 \\
\hline
\end{tabular}

Socioeconomic information sources are the 2009 Census of Agriculture (INE, 2011b) and 2011 Census of Population and Housing (INE, 2011a).

For the statistical analysis, we used Fisher's linear discriminant analysis (LDA) to explore the potential drivers of FSM. Two separated statistical models were fitted: one based on the entire set of socioeconomic and biophysical variables (Complete model) and another based exclusively on biophysical variables (Biophysical model). The discriminant function coefficients were standardized for the two models to evaluate the relative importance of each of the variables as discriminators between different farming systems. Standardizing the values is essential to have a common scale of measurement for comparative purposes, as not all variables are measured in the same units. The unique contribution of variables to the discrimination of FSM specified by the respective discriminant function increases with the increasing of the standardized coefficients, regardless of their signal.

The stepwise forward Wilk's Lambda test procedure was adopted to select the best discriminating variables. Variables with $p<0.05$ were used in LDA and variables that failed to improve the group separation were discarded. Results were evaluated based on a confusion matrix, implemented with leave-one-out cross-validation and on Cohen's Kappa index to correct for agreements occurring by chance between observed and predicted categories (Titus, Mosher, \& Williams, 1984).

Table 3

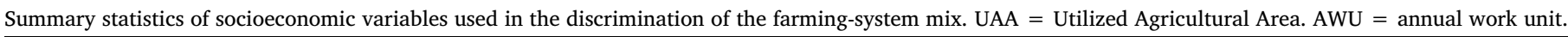

\begin{tabular}{|c|c|c|c|c|}
\hline Description & Mean & SD & Min & Max \\
\hline Share of farms $<5$ ha in total UAA & 0.411 & 0.347 & 0.000 & 1.000 \\
\hline Share of farms $5-50$ ha in total UAA & 0.215 & 0.216 & 0.000 & 0.980 \\
\hline Share of farms greater than 50 ha in total UAA & 0.375 & 0.377 & 0.000 & 1.000 \\
\hline Average number of blocks per holding & 9.1 & 6.9 & 1.0 & 33.1 \\
\hline Average private UAA per block & 0.50 & 0.63 & 0.03 & 6.08 \\
\hline Share of common land in total UAA & 0.417 & 0.355 & 0.000 & 1.000 \\
\hline Population density per $\mathrm{km}^{2}$ & 95.3 & 232.9 & 2.4 & 2583.4 \\
\hline Share of elderly population in resident population & 0.338 & 0.096 & 0.160 & 0.590 \\
\hline Share of working age population in resident population & 0.564 & 0.068 & 0.370 & 0.690 \\
\hline Share of non-family labour in total AWU & 0.044 & 0.047 & 0.000 & 0.310 \\
\hline Average agricultural workers per AWU & 0.129 & 0.109 & 0.000 & 0.640 \\
\hline Average number of farm household members per hectare of private UAA & 1.299 & 0.753 & 0.180 & 3.930 \\
\hline Average number of farm household members per total holdings & 2.738 & 0.390 & 2.000 & 3.910 \\
\hline Share of holdings whose income is exclusively or mainly from agricultural activity in the holding & 0.191 & 0.176 & 0.000 & 0.670 \\
\hline Share of holdings whose income is mainly from retirement pensions & 0.627 & 0.161 & 0.220 & 1.000 \\
\hline Share of holdings whose income is mainly from other external sources & 0.182 & 0.101 & 0.000 & 0.550 \\
\hline Share of holdings whose household consumes more than $50 \%$ of the final production & 0.133 & 0.213 & 0.000 & 0.960 \\
\hline Share of farmers with none level of education & 0.314 & 0.151 & 0.000 & 0.670 \\
\hline Share of farmers with basic level of education & 0.636 & 0.148 & 0.290 & 1.000 \\
\hline Share of farmers with higher level of education & 0.050 & 0.058 & 0.000 & 0.430 \\
\hline Share of farmers aged between 15 and 44 years & 0.109 & 0.079 & 0.000 & 0.550 \\
\hline Share of farmers aged between 45 and 64 years & 0.453 & 0.118 & 0.090 & 0.820 \\
\hline Share of farmers aged more than 65 years & 0.438 & 0.114 & 0.180 & 0.700 \\
\hline Share of total employed population in primary sector & 0.165 & 0.158 & 0.000 & 0.650 \\
\hline Share of total employed population in manufacturing, energy and water & 0.128 & 0.079 & 0.000 & 0.360 \\
\hline Share of total employed population in construction & 0.176 & 0.086 & 0.030 & 0.420 \\
\hline Proportion of total employed population in private services & 0.279 & 0.086 & 0.080 & 0.500 \\
\hline Share of total employed population in public services & 0.206 & 0.092 & 0.000 & 0.460 \\
\hline Share of total employed population in other activities & 0.047 & 0.037 & 0.000 & 0.180 \\
\hline
\end{tabular}


The application of the Complete model allows to analyse the variation of the explanatory power introduced by the addition of socioeconomic variables in the discrimination of the FSM in comparison with a purely Biophysical model. The relationship between the models and the FSM and their respective topographic position (valleys, mountains and plateau), allowed to test, as hypothesized, if the choices made by farmers (number of FSM) in the context referred to in this study increase with the decrease in biophysical constraints and if, in these cases, the socioeconomic context is most determinant for those choices.

ArcGIS 10.5 (ESRI, 2016) was used for mapping and calculate the shares of each variable in the parishes. Statistical analyses were carried out in R version 3.5.1 (R Core Team, 2017), using the "corrplot" package (Wei \& Simko, 2017) for the visualization of correlation matrixes, "psych" package (Revelle, 2018) for the PCA, the "klaR" package (Weihs, Ligges, Luebke, \& Raabe, 2005) for the Wilks' Lambda test and the "MASS" package (Venables \& Ripley, 2002) for the LDA. The extraction of the standardized canonical coefficients of the discriminant functions was carried out using the "candisc" package (Friendly \& Fox, 2017).

\section{Results}

\subsection{Farming systems Mix typology}

The PCA performed on the 26 variables describing each parish's FSM (Table 1) returned seven principal components with eigenvalues greater than one, which retained $78 \%$ of the overall variance in the data (Appendix A). The first principal component (PC1) accounted for $25 \%$ of the total variation in the whole dataset and defined a gradient of intensification on private utilized agricultural area (UAA). The second principal component (PC2) accounted for $19 \%$ of the total variation and represented a gradient of specialization in field crops and livestock production on private permanent pastures (lameiros). The third principal component (PC3) accounted for 9\% of the total variation and defined a gradient relating the share of rye and the specialization in mixed livestock production. The fourth principal component (PC4) accounted for $8 \%$ of the total variation and defined a gradient of specialization in permanent crops. The fifth principal component (PC5) accounted for $7 \%$ of the total variation and defined a gradient of specialization (mainly in sheep). The sixth principal component (PC6) accounted for $6 \%$ of the total variation and defined a gradient of specialization in mixed livestock with a high share of goats. The seventh principal component (PC7) accounted for $4 \%$ of the total variation and represented a gradient in the share of fallow land.

The analysis of the dendrogram (Appendix B) of the cluster analysis led to the selection of a cut-off point corresponding to six main groups, each corresponding to one Farming System Mix (FSM) type. The FSM types were characterized and named based on the analysis of the cluster means of the 26 background variables (Appendix C). A summary of this characterization according to the five main dimensions of the FSM (Table 1) and additionally to the topographic position (Fig. 1b) is presented in Table 4. The "Farming System Mix" row refers to the name of each FSM, which is intended to summarize its main characteristics based on the information present on the remaining rows. "Farmland share" intends to summarize the share of private UAA in total land area, which increases from "residual farmland" to "significant farmland". "Agricultural intensity" summarizes the variation in intensity based on the "average standard output $(€)$ per hectare of total land", "share of irrigable area in total land area" and "average grazing livestock units (LU) per hectare of total land". "Livestock composition" summarizes the shares of each species that dominates the total LU in each FSM. "Agricultural land use" summarizes the dominant agricultural land uses in each FSM. In the situations where agricultural land uses are similar, a plus mark $(+$ and ++$)$ was used to mark specific differences that distinguish the FSM. "Farm specialization pattern" emphasizes the main specific types of farming of the holdings constituting each FSM, which

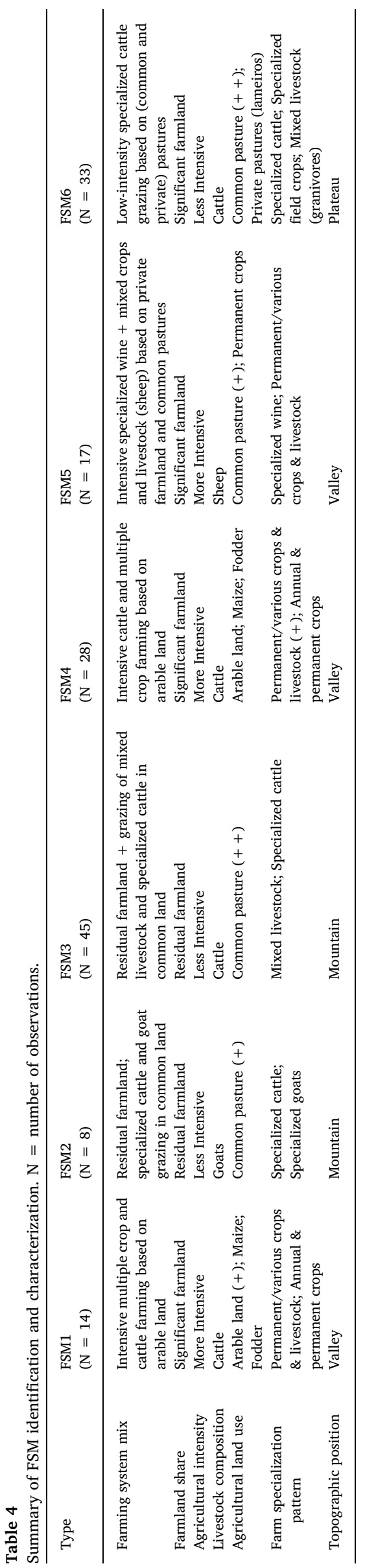




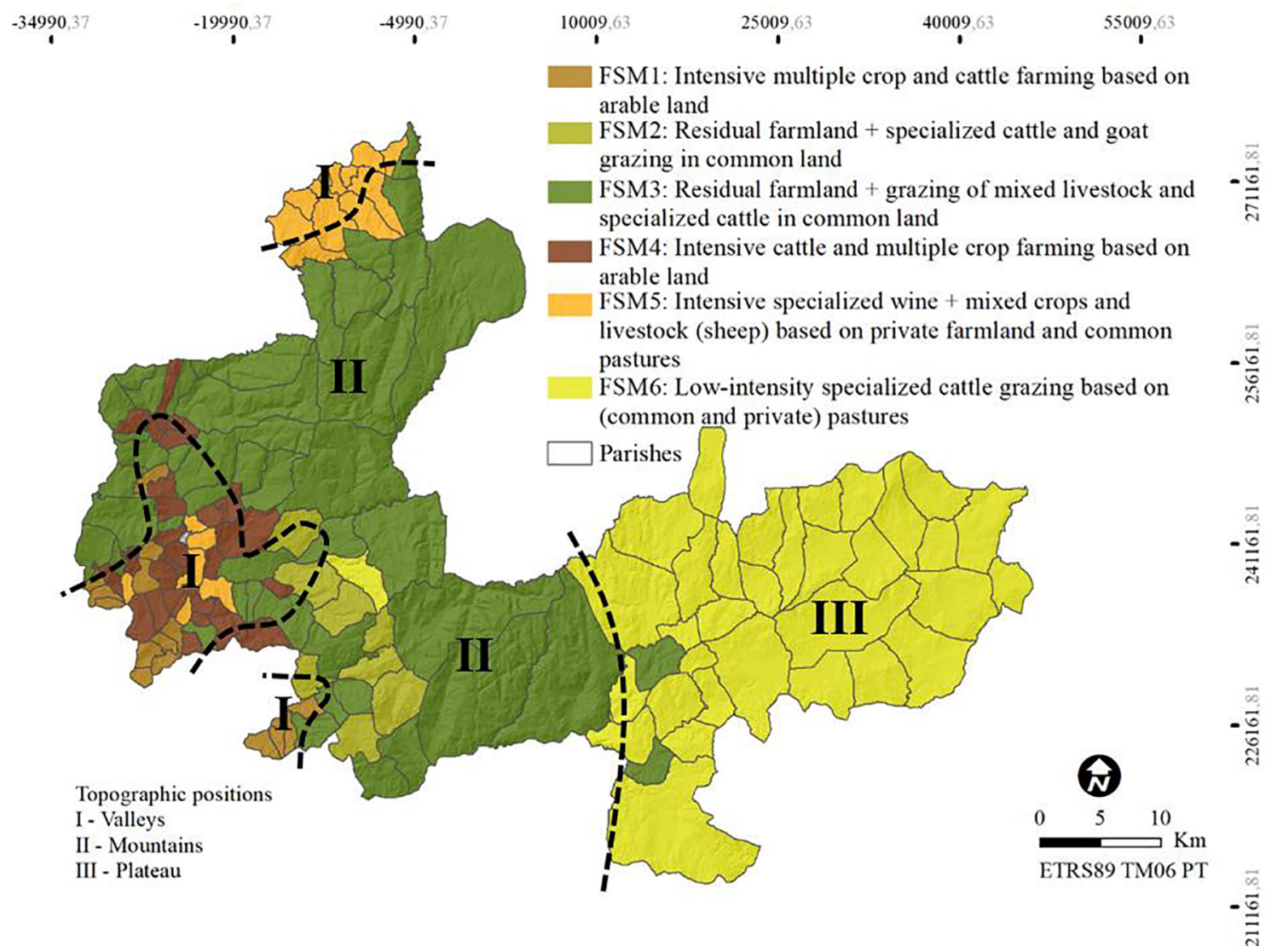

Fig. 2. Map of the Farming System Mixes (FSM) and a conceptual delineation of the different topographic positions: valleys (I), Peneda-Gerês mountains (II) and Barroso plateau (III).

are determined by the relative contribution of the standard output of different activities of each holding to its total standard output. The "Topographic position" row refers to the topographic position in which each FSM has a larger proportion of area (Fig. 3).

The mapping of the FSM types (Fig. 2) revealed that the observations classified within the same FSM type are relatively aggregated in space and associated with a topographic position. The FSM 1, 4 and 5 are mainly associated with the valleys (Fig. 3), with $97 \%, 70 \%$ and $68 \%$ of their total area, respectively, located at this topographic position.

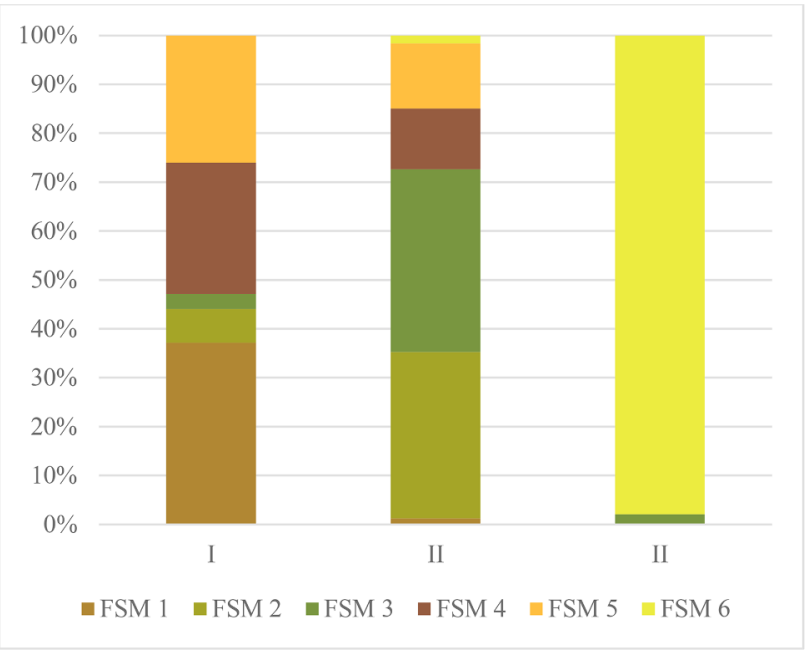

Fig. 3. Distribution of the area (percentage) occupied by the Farming System Mixes (FSM) in different topographic positions: valleys (I), Peneda-Gerês mountains (II) and Barroso plateau (III).
The representativeness of these FSM is low in the mountains and null in the Barroso Plateau.

The FSM 2 and 3 are mostly associated with a mountainous topographical position (Fig. 3), with $82 \%$ and $90 \%$ of their total area, respectively, located at this topographical position. These FSM have a low representativeness in the valleys. The FSM 6 has a great geographical relationship with the Barroso plateau (Fig. 3), with more than $95 \%$ of its total area located at this topographic position. In turn, the presence of this FSM is null in the valleys.

The FSM Intensive multiple crop and cattle farming based on arable land (FSM1) is characterized by significant shares of private farmland, consisting mainly of farming systems with some degree of intensity, with emphasis on the share of irrigable area and high average standard output per hectare of land. Cattle is the predominant species regarding livestock composition and high shares of arable land, maize and fodder characterize farmland use. Farms are mostly specialized in combining permanent/various crops with livestock and annual with permanent crops.

The FSM Residual farmland; specialized cattle and goat grazing in common land (FSM2) is characterized by a residual share of private farmland and consists mainly of low-intensity farming systems, mostly practiced in common land, dominating the land use. Goats are the dominant species in livestock composition and dominate the specialization of farms, where cattle also have some weight.

Relatively similar to FSM2, the FSM Residual farmland + grazing of mixed livestock and specialized cattle in common land (FSM3) is characterized by a residual share of private farmland and consists mainly of low-intensity farming systems mostly practiced in common land. Unlike FSM2, cattle dominate livestock composition and farms are mostly specialized in mixed livestock and cattle. Very similar to FSM1, the FSM Intensive cattle and multiple crop farming based on arable land 
(FSM4) stands out from the previous due to a greater intensity regarding the highest average grazing livestock units (cattle, sheep, goats and equine) per hectare of total land. Moreover, comparing with the FSM1, the share of arable land is lower and the share of farms specialized in the production of permanent/various crops and livestock is higher.

The FSM Intensive specialized wine + mixed crops and livestock (sheep) based on private farmland and common pastures (FSM5) is characterized by significant shares of private farmland, consisting mainly of farming systems with some degree of intensity, with emphasis on the average standard output per hectare of land, the highest in the study area. Sheep are the principal species regarding livestock composition of this FSM, and common permanent pastures and permanent crops, with focus on vineyards, dominate farmland use. Farms are mainly specialized in winegrowing or combine permanent/various crops with livestock (including sheep). The FSM Low-intensity specialized cattle grazing based on (common and private) pastures (FSM6) is characterized by significant shares of private farmland, consisting mainly of low intensity farming systems. Cattle is the main production and hay harvest/grazing takes place in private permanent pastures (lameiros), but especially in common pastures, which cover very significant shares in the landscape. Farms are mainly specialized in the production of cattle, field crops typical of mountainous regions (rye and potato) and mixed livestock, mainly granivores.

\subsection{Discrimination of farming systems Mixes}

Through the application of Complete and Biophysical discriminant models, this study identified the major biophysical and socioeconomic drivers of FSM. As expected, the Complete model, considering both biophysical and socioeconomic variables, revealed a better performance, reaching $70.3 \%$ of success rate, in the discrimination of the FSM, compared to the $62.1 \%$ achieved by the model that only considered biophysical variables. Among the entire set of biophysical (Table 2) and socioeconomic (Table 3) variables considered as potential drivers of FSM, we identified climate (temperature and precipitation), soil depth, slope, non-family labour and farm size as those who showed the greatest discriminatory power.

\subsubsection{Complete model}

In the Complete model, the Wilks' Lambda test (Table 5) returned 10 biophysical and socioeconomic variables that significantly contributed to the separation of FSM types and were subsequently used in the Linear Discriminant Analysis (LDA). Of the five discriminant functions yielded by the LDA, the first discriminant function (LD1) captured $73.4 \%$ of the between-group variance and explained the discrimination between Low-intensity specialized cattle grazing based on (common and private) pastures (FSM6) and all the other FSM (Appendix D). In LD1, the variables related to the climate showed the greatest discriminating ability (Table 6), with FSM6 being associated with higher annual thermal amplitudes, lower average annual temperatures and lower average annual precipitation.

The between-group variance captured by the second discriminant function (LD2) was substantially lower (15.5\%) and contributed mostly for the separation of Intensive specialized wine + mixed crops and livestock (sheep) based on private farmland and common pastures (FSM5) from the other FSM, especially from Residual farmland; specialized cattle and goat grazing in common land (FSM2) and Residual farmland + grazing of mixed livestock and specialized cattle in common land (FSM3) (Appendix E). Average annual precipitation and the share of non-family labour in total annual work unit were the most important variables contributing to LD2 (Table 6).

LD3 captured a marginal $8.4 \%$ of the between-group variance and provided an estimate for discriminating the more intensive FSM geographically related to the valleys, separating FSM1 and FSM4 from FSM5 (Appendix F). The shares of the deepest soils in total land area and of farms with $<5$ ha are the two drivers that most contribute to LD3 (Table 6). The between-group variance captured by the fourth (LD4) and fifth (LD5) functions was very low, reflecting their lower capacity to discriminate FSM.

The overall prediction accuracy of the LDA, with leave-one-out cross validation, reached $70.3 \%$ of success rate, corresponding to an overall Cohen kappa of 0.62 after correcting for chance agreements. Certain FSM are best predicted based on biophysical and socioeconomic variables (Table 9; Appendix J). The FSM with the highest true positive rate, i.e. with the highest number of observations classified correctly, was Low-intensity specialized cattle grazing based on (common and private) pastures (FSM6) (93.9\%; Cohen's kappa $=0.92)$. A high true positive rate was also attributed to Residual farmland + grazing of mixed livestock and specialized cattle in common land (FSM3) (71.1\%; Cohen's kappa $=0.60$ ), Intensive cattle and multiple crop farming based on arable land (FSM4) (67.9\%; Cohen's kappa $=0.39$ ) and Intensive specialized wine + mixed crops and livestock (sheep) based on private farmland and common pastures (FSM5) (76.5\%; Cohen's kappa $=0.76$ ). Unlike the other FSM, Intensive multiple crop and cattle farming based on arable land (FSM1) and Residual farmland; specialized cattle and goat grazing in common land (FSM2) presented a much lower correct classification rate: $35.7 \%$; Cohen's kappa $=0.39$ and $25.0 \%$; Cohen's kappa $=0.25$, respectively.

\subsubsection{Biophysical model}

In Biophysical model, the Wilks' Lambda test (Table 7) returned seven variables that significantly contributed to the separation of FSM. Of the five discriminant functions yielded by the LDA, the first discriminant function (LD1) captured $80.3 \%$ of the between-group variance and, as in the Complete model, explained the discrimination between Low-intensity specialized cattle grazing based on (common and private) pastures (FSM6) and all the other FSM (Appendix G). In LD1, the biophysical variables related to climate and the share of deeper soils in total land area showed the greatest discriminating ability (Table 8).

The between-group variance captured by LD2 was substantially lower (11.5\%) and contributed mostly for the separation of Intensive

Table 5

Summary of the Wilk's Lambda stepwise forward variable selection test performed on the variables. With a 0.05 threshold for the appropriate p value of the F-statistic of the partial Wilk's Lambda (p value), 10 variables were retained. UAA = Utilized Agricultural Area. AWU = annual work unit.

\begin{tabular}{|c|c|c|c|c|c|}
\hline Description & Wilk's lambda & F statistics overall & $\mathrm{p}$ value overall & F statistics & $\mathrm{p}$ value \\
\hline Average annual temperature & 0.324 & 57.942 & 0.000 & 57.942 & 0.000 \\
\hline Average annual precipitation & 0.141 & 45.817 & 0.000 & 35.719 & 0.000 \\
\hline Average annual thermal amplitude & 0.100 & 32.838 & 0.000 & 11.244 & 0.000 \\
\hline Share of total land area with soil depth greater than $50 \mathrm{~cm}$ & 0.073 & 27.125 & 0.000 & 10.063 & 0.000 \\
\hline Share of non-family labour in total AWU & 0.058 & 23.150 & 0.000 & 6.958 & 0.000 \\
\hline Average number of farm household members per hectare of private UAA & 0.045 & 20.934 & 0.000 & 7.590 & 0.000 \\
\hline Share of farms $<5$ ha in total UAA & 0.037 & 19.150 & 0.000 & 6.181 & 0.000 \\
\hline Share of farmers with none level of education & 0.032 & 17.343 & 0.000 & 3.774 & 0.003 \\
\hline Share of farmers with higher level of education & 0.028 & 15.955 & 0.000 & 3.590 & 0.004 \\
\hline Average number of farm household members per total holdings & 0.025 & 14.844 & 0.000 & 3.399 & 0.006 \\
\hline
\end{tabular}


Table 6

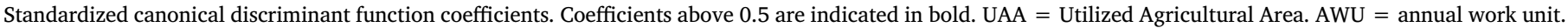

\begin{tabular}{|c|c|c|c|c|c|}
\hline Description & LD1 & LD2 & LD3 & LD4 & LD5 \\
\hline Average annual temperature & -0.921 & 0.170 & -0.235 & -0.477 & 0.578 \\
\hline Average annual precipitation & -0.501 & 0.710 & 0.007 & 0.105 & -0.249 \\
\hline Average annual thermal amplitude & 0.548 & 0.430 & 0.346 & -0.283 & 0.164 \\
\hline Share of total land area with soil depth greater than $50 \mathrm{~cm}$ & 0.204 & -0.460 & 0.596 & -0.004 & -0.549 \\
\hline Share of non-family labour in total AWU & -0.176 & -0.530 & -0.209 & 0.040 & -0.394 \\
\hline Average number of farm household members per hectare of private UAA & -0.439 & -0.140 & -0.352 & -0.121 & -0.307 \\
\hline Share of farms $<5$ ha in total UAA & -0.139 & -0.400 & 0.588 & 0.133 & -0.016 \\
\hline Share of farmers with none level of education & 0.143 & -0.280 & 0.428 & 0.288 & -0.299 \\
\hline Share of farmers with higher level of education & -0.009 & -0.320 & -0.398 & 0.367 & 0.243 \\
\hline Average number of farm household members per total holdings & -0.163 & 0.230 & 0.209 & 0.784 & 0.266 \\
\hline Variance $(\%)$ & 73.4 & 15.5 & 8.4 & 1.4 & 1.3 \\
\hline
\end{tabular}

specialized wine + mixed crops and livestock (sheep) based on private farmland and common pastures (FSM5) from Residual farmland; specialized cattle and goat grazing in common land (FSM2) and Residual farmland + grazing of mixed livestock and specialized cattle in common land (FSM3) (Appendix H). Average annual precipitation, average annual thermal amplitude and the share of deepest soils in total land area were the most important variables contributing to LD2 (Table 8).

LD3 captured a marginal $6.1 \%$ of the between-group variance and provided an estimate for discriminating the more intensive FSM geographically related to the valleys, separating FSM1 and FSM4 from FSM5 (Appendix I). Although almost all the variables have contributed to this function, the average thermal amplitude showed a greater discriminatory importance (Table 8). As in the Complete model, the between-group variance captured by LD4 and LD5 functions was very low, reflecting their lower capacity to discriminate FSM.

The overall prediction accuracy of the LDA, with leave-one-out cross validation, reached $62.1 \%$ of success rate, corresponding to an overall Cohen kappa of 0.51 after correcting for chance agreements. As in the previous analysis, there are differences in the prediction of different FSM (Table 9; Appendix K). Considering only biophysical variables as predictors of FSM, Low-intensity specialized cattle grazing based on (common and private) pastures (FSM6) maintained the highest proportion of correct classifications (90.9\%; Cohen's kappa $=0.90$ ) showing a $3 \%$ reduction in prediction accuracy if comparing with the LDA based on biophysical and socioeconomic variables.

Residual farmland + grazing of mixed livestock and specialized cattle in common land (FSM3) (68.9\%; Cohen's kappa $=0.47$ and Intensive cattle and multiple crop farming based on arable land (FSM4) (71.4\%; Cohen's kappa $=0.39$ ) maintained high proportions of correct classifications. In the Intensive specialized wine + mixed crops and livestock (sheep) based on private farmland and common pastures (FSM5) $(52.9 \%$; Cohen's kappa $=0.61)$ there was a marked reduction of $23.6 \%$ in the proportion of correct classifications. The highest decrease in correct classifications corresponds to Intensive multiple crop and cattle farming based on arable land (FSM1) $(0.00 \%$; Cohen's kappa $=-0.04)$ and Residual farmland; specialized cattle and goat grazing in common land (FSM2) $(0.00 \%$; Cohen's kappa $=-0.02)$ that were both assigned with zero correct classifications. The negative kappa assigned to these FSM represents an agreement among raters worse than expected.

\section{Discussion}

\subsection{Getting landscape-level BES outcomes through policies that drive FS choice}

Farming systems reflect farmers' productive choices such as the type of crop, livestock or the level of chemical inputs, considered as descriptors. These descriptors can be grouped into several dimensions (e.g. land use, intensity), which vary according to the action of biophysical (e.g. climate, soil, slope) and socioeconomic (e.g. farm size, farmer's education) drivers of farmers' choices.

Many studies mix descriptors and drivers in their analysis, which affects their ability to understand the dynamics of agricultural landscapes. Farm size, for example, is often considered as a descriptor of farming systems (e.g. Andersen, 2017), but the fact that diverse farm sizes coexist in a landscape does not mean that farmers have the possibility to easily choose the size of their farm. Indeed, in many contexts, farm size or ownership structure is often a major structural constraint of farming system choice by farmers (Pfeifer, Jongeneel, Sonneveld, \& Stoorvogel, 2009; Pierpaoli, Carli, Pignatti, \& Canavari, 2013; Ribeiro et al., 2014). Land is a non-reproducible factor of production and therefore the increase of farm size for one farmer depends on the decrease of farm size for others or the expansion of the agricultural frontier. These structural adjustments are usually slow and usually depend on many exogenous factors (demography, development of other sectors in the economy, policies), and are thus beyond farmer's shortterm productive decisions.

The separation between descriptors and drivers is not always straightforward and depends on the socioecological context of the study area. So, even if farm size is often a driver, variables that we have considered as a descriptor, i.e., that mostly depend on farmer's decisions, can be considered drivers in different contexts. For example, in our study area in Northern Portugal, the share of irrigable area was considered as a descriptor of farming systems given the easy access that

Table 7

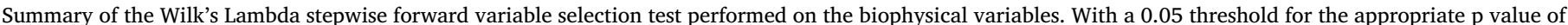
the F-statistic of the partial Wilk's Lambda ( $p$ value), seven variables were retained.

\begin{tabular}{|c|c|c|c|c|c|}
\hline Description & Wilk's lambda & F statistics overall & $\mathrm{p}$ value overall & F statistics & $\mathrm{p}$ value \\
\hline Average annual temperature & 0.324 & 57.942 & 0.000 & 57.942 & 0.000 \\
\hline Average annual precipitation & 0.141 & 45.817 & 0.000 & 35.719 & 0.000 \\
\hline Average annual thermal amplitude & 0.100 & 32.838 & 0.000 & 11.244 & 0.000 \\
\hline Share of total land area with soil depth greater than $50 \mathrm{~cm}$ & 0.073 & 27.125 & 0.000 & 10.063 & 0.000 \\
\hline Share of total land area with soil depth between 25 and $50 \mathrm{~cm}$ & 0.060 & 22.824 & 0.000 & 6.017 & 0.000 \\
\hline Elevation range $(\mathrm{m})$ & 0.053 & 19.383 & 0.000 & 3.255 & 0.008 \\
\hline Share of total land area with slopes between 0 and $12 \%$ & 0.048 & 16.997 & 0.000 & 2.985 & 0.014 \\
\hline
\end{tabular}


Table 8

Standardized canonical discriminant function coefficients. Coefficients above 0.5 are indicated in bold.

\begin{tabular}{|c|c|c|c|c|c|}
\hline Description & LD1 & LD2 & LD3 & LD4 & LD5 \\
\hline Average annual temperature & -1.385 & 0.370 & -0.580 & 0.450 & -0.159 \\
\hline Average annual precipitation & -0.283 & -0.790 & 0.700 & -0.210 & -0.314 \\
\hline Average annual thermal amplitude & 0.718 & -0.610 & 1.050 & 0.180 & -0.447 \\
\hline Share of total land area with soil depth greater than $50 \mathrm{~cm}$ & 0.845 & 0.510 & 0.820 & -1.350 & 0.152 \\
\hline Share of total land area with soil depth between 25 and $50 \mathrm{~cm}$ & 0.740 & 0.130 & 0.200 & -0.500 & -0.019 \\
\hline Elevation range $(\mathrm{m})$ & -0.182 & 0.110 & -0.870 & -0.680 & -0.558 \\
\hline Share of total land area with slopes between 0 and $12 \%$ & 0.003 & 0.310 & -0.730 & -0.110 & -0.966 \\
\hline Variance (\%) & 80.3 & 11.5 & 6.1 & 1.8 & 0.2 \\
\hline
\end{tabular}

farmers have to the water resource (e.g. rivers, springs, waterways), associated with high levels of precipitation. In the drier South of Portugal, the irrigable area depends a lot on the existence of infrastructures for water storage and its conduction (e.g. dams, dikes, irrigation channels) that are beyond the investment capacity of most farmers. Thus, in this particular context, the access to water from a public irrigation infrastructure is a major driver of farmers' decisions.

The separation between descriptors and drivers is clearer in studies carried out at a single point in time (cross-section data) and focused on short to medium term productive decisions. When performing spatiotemporal analysis, it is expected to find interrelationships and even changes between many of the socioecological variables (Niemiec et al., 2019), which may make it difficult to separate the farming system descriptors from the drivers of farming system choice in some cases.

Farmer's decisions have direct repercussions on the spatial distribution of agricultural activities both at the farm-level and at the landscape level. Studies which assessed systems diversity at the farmlevel (e.g. Dixon et al., 2001; van de Steeg et al., 2010) and at a global scale (e.g. van Asselen and Verburg, 2012) ignored the effect of farmers decisions on the landscape as a whole, which would be relevant to the conservation of biodiversity and many ecosystem services. In fact, several studies show that the farming system composition in a landscape affects not only species richness but also species diversity (e.g. Gil-Tena et al., 2015; Santana et al., 2016), underlining a gap in farming system research between farm and landscape levels.

While farm-level data is often lacking or is difficult to acquire, the Farming System Mix (FSM) approach relies on statistical data from agricultural census at parish level to bridge this gap, enabling to address different scales. While, for example, the intensity dimension is referred to the parish-level, the specialization pattern dimension provides information about the specialization pattern at farm-level. Since BES essentially respond to changes at landscape-level, but policies are designed to act mainly by affecting changes at the farm-level, this approach can be useful as a tool for bridging both scales. Although the variation that exists at household level becomes imperceptible, working at this level enables to capture landscape patterns and spatially relate them with biophysical (e.g. soil, slope, aspect, precipitation, temperature) and socioeconomic data (e.g. population density, employment, education).

In a broader policy perspective, understanding the landscape patterns produced by spatial combinations of different farming systems, i.e. by FSM, may be of utmost relevance for the characterization of agricultural landscapes, thus helping to inform and design policies aimed to affect farming system choice to promote BES. Moreover, by using agricultural census statistical data (e.g. livestock units, irrigable area, standard output), the FSM approach enables to study the management intensity opening the possibility to further analyse its environmental impacts, which is not possible in studies based only on land use and land cover data (Calvo-Iglesias, Fra-Paleo, \& Diaz-Varela, 2009; Dang \& Kawasaki, 2017; Plieninger et al., 2016)

The five dimensions that characterize the FSM (farmland share (share of utilised agricultural area), average intensity (e.g. per hectare output), livestock composition (e.g. share of cattle in total livestock), agricultural land use (e.g. share of arable land) and farm-level specialization pattern (e.g. share of farms specialized in wine)) can provide indicators related to BES. For example, the smaller farmland shares characterizing FSM2 (Residual farmland; specialized cattle and goat grazing in common land) and FSM3 (Residual farmland + grazing of mixed livestock and specialized cattle in common land) may reveal a greater fuel continuity in the landscape and therefore an increased risk of fire. More intensive FSM, like FSM1 (Intensive multiple crop and cattle farming based on arable land) and FSM 4 (Intensive cattle and multiple crop farming based on arable land), although associated with higher food production, may have larger negative impacts on biodiversity. The low intensity and large farmland share of FSM6 (Low-intensity specialized cattle grazing based on (common and private) pastures) may represent a potential habitat for farmland birds. The high intensity and specialization in wine of FSM5 (Intensive specialized wine + mixed crops and livestock (sheep) based on private farmland and common pastures) may indicate a simplified landscape.

Depending on the availability of data, it would be interesting to move towards the development of a spatio-temporal analysis, incorporating policy (e.g. agri-environmental schemes) and market (e.g. prices) related variables. This would increase awareness of farmers' temporal response to policy implementation and the repercussions they have on landscape composition. A farm-level study, conducted in a High Nature Value farmland area in southern Portugal, analysed the effects that economic incentives had on farmers' choice between 2000 and 2010 and concluded that, for example, a slight increase was sufficient to rise the proportion of traditional farming systems in the region

Table 9

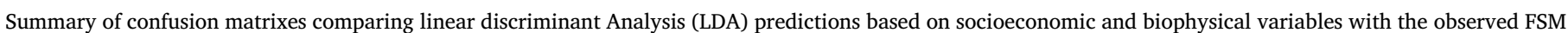
classifications and overall prediction accuracy of LDA for Complete and Biophysical models.

\begin{tabular}{|c|c|c|c|}
\hline \multirow[t]{2}{*}{ Farming System Mixes (FSM) } & \multirow[t]{2}{*}{ Observations } & \multicolumn{2}{|c|}{ Correctly assigned (\%) } \\
\hline & & COMPLETE & BIOPHYSICAL \\
\hline FSM1: Intensive multiple crop and cattle farming based on arable land & 14 & 35.7 & 0.0 \\
\hline FSM2: Residual farmland; specialized cattle and goat grazing in common land & 8 & 25.0 & 0.0 \\
\hline FSM3: Residual farmland + grazing of mixed livestock and specialized cattle in common land & 45 & 71.1 & 68.9 \\
\hline FSM4: Intensive cattle and multiple crop farming based on arable land & 28 & 67.9 & 71.4 \\
\hline FSM5: Intensive specialized wine + mixed crops and livestock (sheep) based on private farmland and common pastures & 17 & 76.5 & 52.9 \\
\hline FSM6: Low-intensity specialized cattle grazing based on (common and private) pastures & 33 & 93.9 & 90.9 \\
\hline Total & 145 & - & - \\
\hline
\end{tabular}


(Ribeiro et al., 2018). Hinojosa et al. (2019) studied the conversion of grasslands and drivers of those changes between 1990 and 2010 in a relatively homogeneous mountainous region (Tyrol, Alps), but shared by two different political institutions (Austria and Italy) and concluded that the conversion was heterogeneous in both countries revealing the effect of regional integration on land use decisions.

\subsection{The strength of biophysical constraints and the role of socioeconomic drivers}

Agricultural landscapes are the result of the interaction of biophysical and socioeconomic factors that drive farmers' decisions about what to produce and how to produce it. In a given time, there is a wide range of socioeconomic variables (e.g. population density, market linkages, technology) that can be assumed to be constant. In this context, certain biophysical variables emerge as the most relevant constraints for farmers' productive options, establishing the possibility set (Santos, 1992) within which farmers make their choices regarding farming systems. When this possibility set allows for a wider range of choices, farmers' choices are primarily determined by socioeconomic drivers. An important caveat applies here: by using cross-section data to test our hypothesis, the effect of long-term socioeconomic changes in reconfiguring the room that biophysical constraints leave for socioeconomic variables to act as drivers of farming system choice is not considered. For example, in past contexts, when there was greater availability of agricultural labour and less dependence on mechanization, the level of constraint on farming system choice associated to slope would probably be much smaller. To address this problem, different data and a different hypothesis would be appropriate.

In mountain landscapes, biophysical gradients (e.g. climate, slopes, soil) are especially well marked and have a key impact on farmers' decisions, making these landscapes the ideal setting for testing the importance of socioeconomic factors regarding the choice of farming systems. Although the biophysical gradients of the mountainous region of northern Portugal are not as striking as, for example, in the Alps, where about $40 \%$ of the area is above average altitudes of $2000 \mathrm{~m}$, revealing large variations in slope and highly conditioning grasslands spatial distribution (Hinojosa et al., 2019), they are sufficiently marked to promote great variations in climate and soil conditions.

The pronounced relation between the FSM (Fig. 2) and different topographical positions support the relation that farmers have with the landscape. This relation is conceptually illustrated in Fig. 4, where the biophysical environment the socioeconomic context are represented by two gradients (horizontal and vertical). While more productive choices have been made by farmers in the valleys (three FSM), the number of observed productive choices decreases towards the mountain (two FSM types) and the plateau (one FSM type).

It should be noted that Barroso plateau (Fig. 1b.III) is not necessarily the most restrictive regarding the choices made by farmers. Although this region emerges at the top of the "pyramid" (Fig. 4), associated only with the FSM6 (Low-intensity specialized cattle grazing based on (common and private) pastures), this FSM is characterized by a high heterogeneous specialization pattern, where in the same parish there are farms specialized in animal production (mainly cattle) and farms specialized in field crops (e.g. rye, potato) (Appendix C). In the mountain (Fig. 1b.II), where there are two FSM (Residual farmland; specialized cattle and goat grazing in common land (FSM2) and Residual farmland + grazing of mixed livestock and specialized cattle in common land (FSM3)), a more homogeneous pattern of specialization is found, in which farms specialized in animal production (cattle and goats) are predominant, largely due to the association of this region with great slopes.

As hypothesized, the FSM located in the valleys, where the most favourable conditions for agriculture are found and thus more options are open to farmers, choices among these options were predominantly discriminated by socioeconomic variables. In contrast, the discrimination of the FSM located in the mountain and plateau, i.e. in the areas where the possibility set of choices were narrower, was predominantly made by biophysical variables.

Biophysical variables related to climate and soil play a strong role in the discrimination between the FSM related with different topographic positions, i.e., in the vertical gradient, such as Low-intensity specialized cattle grazing based on (common and private) pastures (FSM6), located in the plateau, from FSM1, FSM4 and FSM5 located in the valleys. The high accuracy of the prediction of Low-intensity specialized cattle grazing based on (common and private) pastures (FSM6) based only on biophysical factors is due to the distinct climate that characterizes the Barroso plateau, as opposed to the rest of the study area, with low averages of precipitation and temperature and higher thermal amplitudes (Appendix L), restricting the viability to grow specific crops that may thrive in other FSM located at different topographic positions. The importance of soil in discriminating different FSM in the study area is highly related with the marked heterogeneity found between lowlands, where the share of deeper soils is greater, allowing a wider range of options relating the farming system choice, and the highlands (mountains and plateau) where the soil is generally thinner and slopes often higher. Given the particular characteristics of the study area, it was expected that the biophysical variables would reveal a great power in the discrimination of the FSM.

Still, even in a mountain area characterized by strong biophysical (Appendix L) gradients, it can be concluded that the socioeconomic context plays a key role in farmers' choices, as socioeconomic variables are essential for the discrimination between FSM types associated with similar topographic situations (horizontal gradient). For example, the share of non-family labour plays an important role in the discrimination of Intensive specialized wine + mixed crops and livestock (sheep) based on private farmland and common pastures (FSM5), highly demanding in external workforce due to the working peak of grape harvest, from the other FSM types, including the other two FSM types located with the valleys.

Although through the Biophysical model it is possible to predict several FSM with great accuracy, the exclusion of the socioeconomic variables led to a significant reduction in the prediction accuracy of several FSM types, even in a mountainous area, where the biophysical factors exert a bigger influence on the distribution of activities in the landscape. The Biophysical model also failed to predict two of the six FSM, which may be explained by a lower dependence of these FSM on biophysical conditions (e.g. intensive farming systems where the biophysical environment allows for several choices, which are made on socioeconomic grounds), or, in contrast, extremely low-intensity farming systems that can easily adapt to different biophysical conditions (Ribeiro et al., 2016).

Within the observed choices made by farmers in the study area, they must have made the one that best fitted the biophysical environment and socioeconomic context. Obviously, if this possibility set changes over time, other choices may emerge, potentially promoting major land-use changes in the landscape. Where farmers' choices turn out to be unsustainable and in the absence of alternatives, the trend may be towards farmland abandonment, with direct repercussions on biodiversity and ecosystem services.

\section{Conclusions}

In mountain areas, changes in the farming system component are linked with processes such as farmland abandonment or intensification, affecting biodiversity and ecosystem services (BES). The separation between descriptors of farming systems (variables that depend on farmers' decisions) and drivers of farming system choice (variables that influence these decisions) allows us to better understand the context in which farmers make their choices and also to isolate the drivers behind those choices, potential targets for manipulation by policies aimed at supporting BES. 


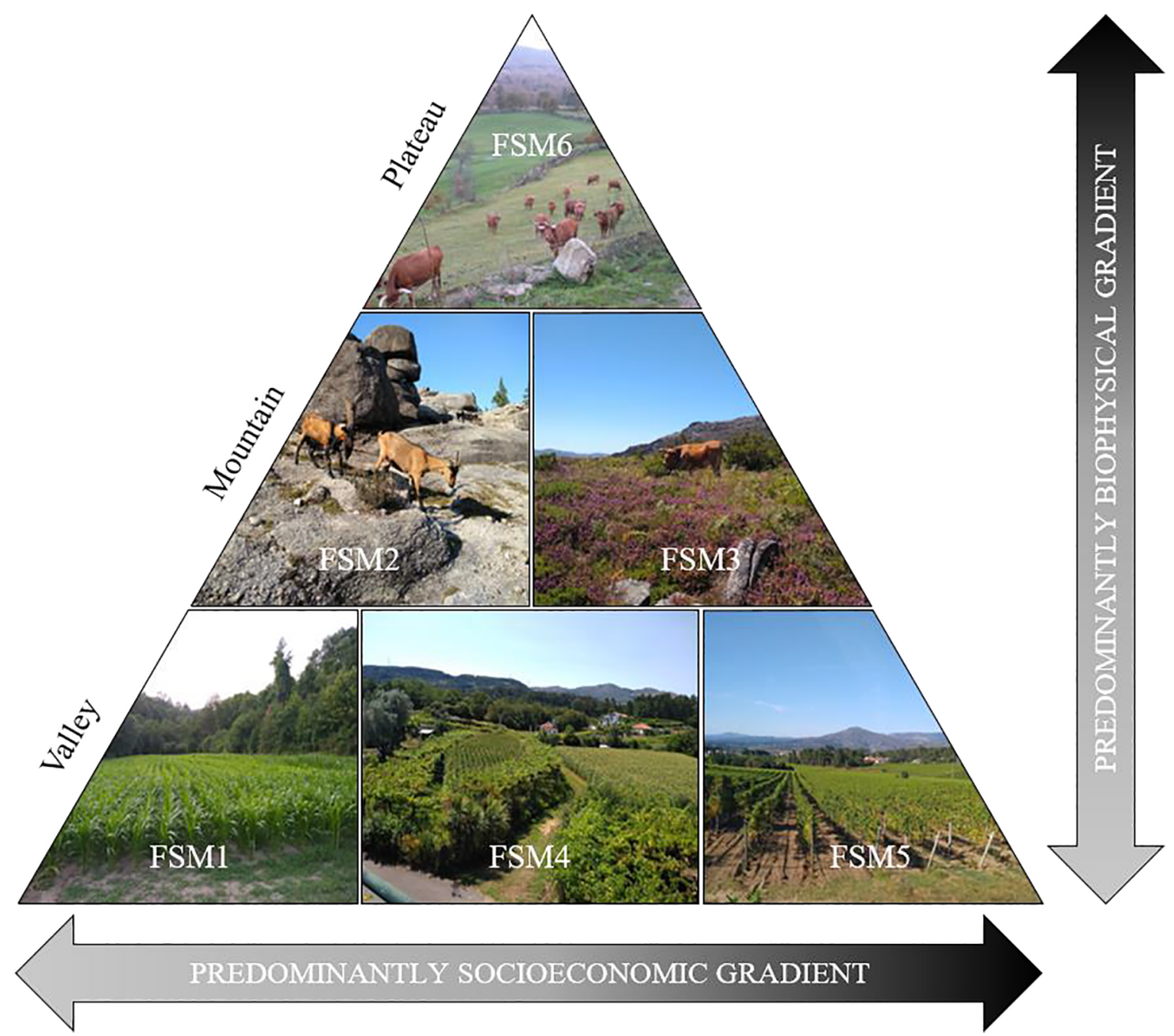

Fig. 4. 'Pyramid' illustrating the conceptual relation between the six Farming System Mixes (FSM) with the topographic position they occupy in the landscape. The two gradients (horizontal and vertical) represents the biophysical and socioeconomic constraints conditioning farming systems choice. FSM1: Intensive multiple crop and cattle farming based on arable land; FSM2 Residual farmland; specialized cattle and goat grazing in common land; FSM3: Residual farmland + grazing of mixed livestock and specialized cattle in common land; FSM4: Intensive cattle and multiple crop farming based on arable land; FSM5: Intensive specialized wine + mixed crops and livestock (sheep) based on private farmland and common pastures; FSM6: Low-intensity specialized cattle grazing based on (common and private) pastures.

In a given time and context, the biophysical environment tends to define the set of possible choices available for farmers. When the biophysical environment allows this set to expand, the importance of the socioeconomic drivers, main target for policy makers, in determining farmers' choices increases, thereby increasing the opportunities for policy application.

Even in a mountain area, characterized by strong biophysical gradients which strongly influence the distribution of agricultural activity in the landscape, it has been demonstrated that socioeconomic drivers, such as farm size and labour, are important determinants of farming systems. The relevance of socioeconomic drivers in affecting the choice of farmers has proven to be particularly decisive in valleys, where biophysical conditions are more favourable to the development of agricultural practices, comparing to mountain and plateau areas.

While farming system research often relies on farm-level data, working with agricultural census data at parish level proved to be a methodological contribution to the cases where no data are available at that level. At parish level, the spatial combination of different farming systems, i.e. the Farming System Mixes, allows to integrate the landscape context in farming system research, thus allowing the analysis of the biophysical and socioeconomic drivers of farming system choice at this level and relate them to BES.

\section{Acknowledgments}

This study was supported by Fundação para a Ciência e a Tecnologia I.P. (FCT), Portugal, through funding to LEAF, Linking Landscape, Environment, Agriculture and Food Research Centre (UID/AGR/ 04129/2013), to Forest Research Centre (UID/AGR/00239/2019), to João Ferreira Silva (SFRH/BD/109814/2015). AL was supported by national funds through FCT - Fundação para a Ciência e a Tecnologia, I.P., in the context of the Transitory Norm - DL57/2016/CP1440/ CT0001. This paper is a result of the project POCI-01-0145-FEDER016664 - PTDC/AAG-REC/5007/2014 - FARSYD - Farming systems as tool to support policies for effective conservation and management of high nature value farmlands, supported by Norte Portugal Regional Operational Programme (NORTE 2020), under the PORTUGAL 2020 Partnership Agreement, through the European Regional Development Fund (ERDF). The first author would like to thank all the members of LEAF/ISA/UL who contributed to this study. 
Appendix A. Variable scores in the seven principal components (PC). Loadings above 0.5 are indicated in bold. UAA = Utilized agricultural Area. $\mathrm{LU}=$ livestock units. Total grazing $\mathrm{LU}=$ cattle + sheep + goats + equine.

\begin{tabular}{|c|c|c|c|c|c|c|c|}
\hline Description & PC1 & PC2 & PC3 & PC4 & PC5 & PC6 & PC7 \\
\hline \multicolumn{8}{|l|}{ Farmland share } \\
\hline Share of private UAA in total land area & 0.72 & 0.51 & 0.16 & 0.30 & -0.12 & -0.04 & 0.02 \\
\hline \multicolumn{8}{|l|}{ Agricultural intensity } \\
\hline Average standard output $(€)$ per hectare of total land & 0.80 & -0.08 & -0.09 & 0.32 & -0.18 & -0.14 & -0.02 \\
\hline Share of irrigable area in total land area & 0.78 & 0.24 & -0.12 & 0.27 & 0.03 & -0.03 & -0.16 \\
\hline Average grazing LU per hectare of total land & 0.38 & 0.38 & -0.55 & 0.30 & -0.01 & -0.01 & -0.28 \\
\hline \multicolumn{8}{|l|}{ Livestock composition } \\
\hline Share of cattle in total grazing LU & 0.16 & 0.63 & -0.31 & -0.40 & -0.13 & -0.34 & 0.06 \\
\hline Share of sheep in total grazing LU & 0.12 & -0.58 & 0.43 & 0.38 & 0.39 & -0.02 & -0.12 \\
\hline Share of goats in total grazing LU & -0.26 & -0.24 & -0.05 & 0.25 & -0.49 & 0.64 & 0.02 \\
\hline \multicolumn{8}{|l|}{ Agricultural land use } \\
\hline Share of arable land & 0.85 & 0.19 & -0.15 & 0.04 & 0.20 & 0.23 & 0.21 \\
\hline Share of permanent pastures in commons & -0.51 & 0.21 & 0.10 & 0.14 & 0.15 & -0.16 & 0.02 \\
\hline Share of permanent pastures in private land (lameiros) & 0.02 & 0.81 & 0.19 & 0.21 & -0.13 & -0.06 & -0.13 \\
\hline Share of permanent crops & 0.60 & -0.47 & 0.23 & 0.31 & -0.31 & -0.29 & 0.02 \\
\hline Share of kitchen garden & 0.87 & -0.23 & -0.11 & -0.11 & 0.07 & 0.11 & 0.08 \\
\hline Share of fallow land & 0.51 & -0.23 & 0.00 & -0.05 & -0.02 & -0.04 & 0.73 \\
\hline Share of rye & 0.05 & 0.59 & 0.53 & 0.07 & 0.09 & 0.14 & 0.11 \\
\hline Share of maize & 0.87 & 0.05 & -0.09 & -0.16 & 0.10 & 0.20 & 0.09 \\
\hline Share of potato & 0.34 & 0.66 & 0.39 & -0.07 & 0.07 & 0.21 & -0.24 \\
\hline Share of annual fodder crops & 0.79 & 0.23 & -0.20 & -0.08 & 0.11 & 0.19 & -0.15 \\
\hline \multicolumn{8}{|l|}{ Farm specialization pattern } \\
\hline Share of private UAA used by farms specialized in field crops & -0.14 & 0.70 & 0.37 & 0.02 & -0.01 & -0.04 & 0.21 \\
\hline Share of private UAA used by farms specialized in wine & 0.29 & -0.57 & 0.35 & 0.40 & -0.32 & -0.28 & -0.07 \\
\hline Share of private UAA used by farms specialized in cattle & -0.38 & 0.57 & -0.45 & 0.16 & -0.22 & -0.26 & 0.12 \\
\hline Share of private UAA used by farms specialized in sheep & -0.24 & -0.16 & 0.01 & 0.43 & 0.60 & 0.10 & 0.10 \\
\hline Share of private UAA used by farms specialized in goats & -0.13 & -0.09 & -0.48 & 0.19 & 0.63 & 0.20 & 0.01 \\
\hline Share of private UAA used by mixed livestock farms & -0.28 & -0.06 & -0.17 & 0.15 & -0.50 & 0.65 & 0.02 \\
\hline Share of private UAA used by farms combining annual and permanent crops & 0.38 & -0.32 & 0.24 & -0.54 & -0.04 & 0.07 & 0.00 \\
\hline Share of private UAA used by mixed livestock farms, mainly granivores and grazing livestock & 0.01 & 0.51 & 0.54 & -0.10 & 0.15 & 0.27 & 0.01 \\
\hline Share of private UAA used by farms combining permanent/various crops and livestock & 0.37 & -0.47 & 0.10 & -0.53 & 0.04 & 0.01 & -0.35 \\
\hline Variance explained by the PC's (\%) & 25.0 & 19.0 & 9.0 & 8.0 & 7.0 & 6.0 & 4.0 \\
\hline
\end{tabular}

Appendix B. Hierarchical cluster analysis dendrogram with the dashed line indicating the cut-off point in six groups.

Clust er Dendrogram

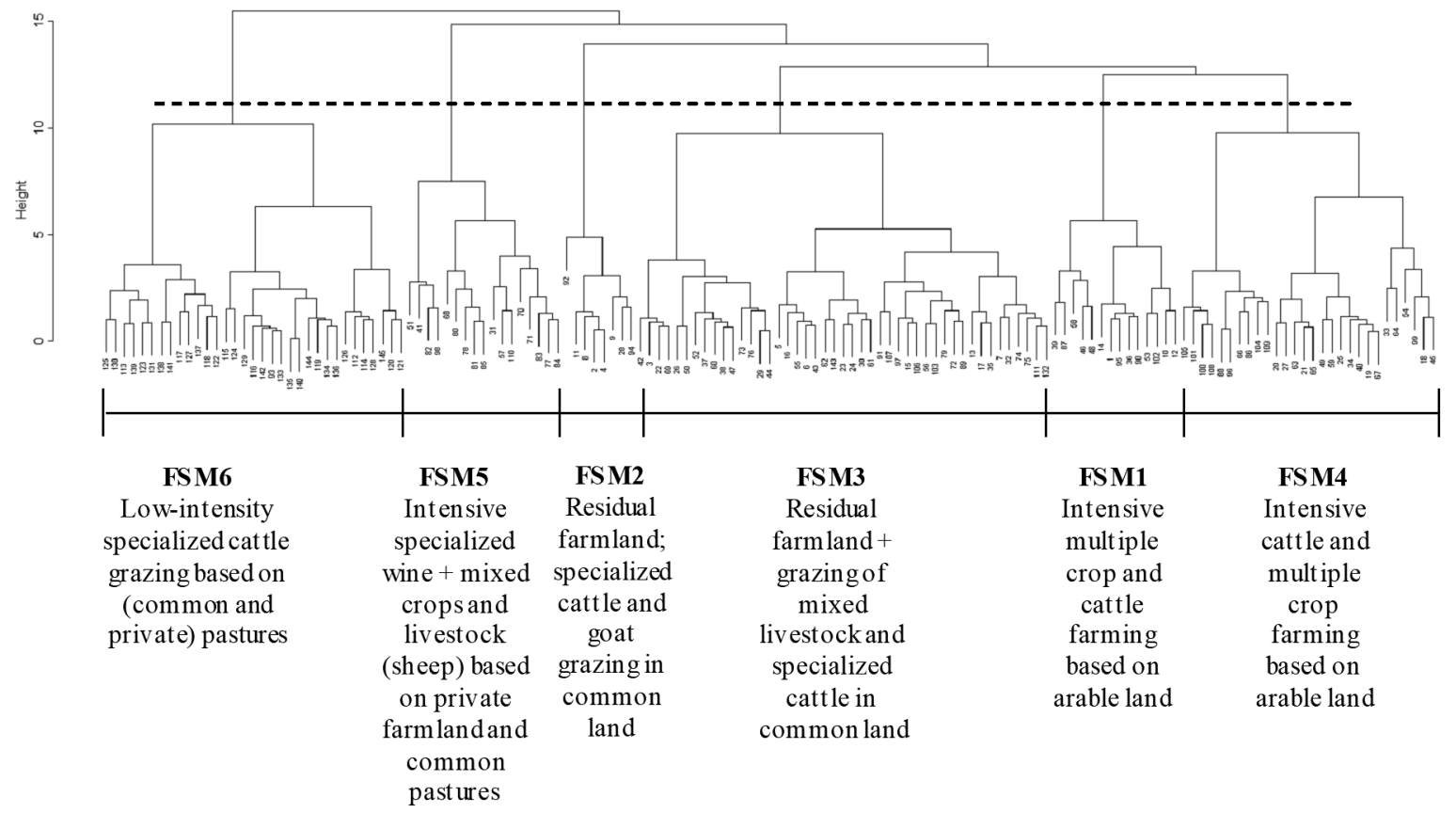


Appendix C. Group means for individual farming system mixes in relation to background variables, with standard deviation in brackets. The values, major or minor, that stand out are indicated in bold. UAA = Utilized agricultural Area. LU = livestock units. Total grazing $\mathbf{L U}=$ cattle + sheep + goats + equine. $\mathbf{N}=$ number of observations.

\begin{tabular}{|c|c|c|c|c|c|c|}
\hline Description & $\begin{array}{l}\text { FSM1 } \\
(\mathrm{N}=14)\end{array}$ & $\begin{array}{l}\text { FSM2 } \\
(\mathrm{N}=8)\end{array}$ & $\begin{array}{l}\text { FSM3 } \\
(\mathrm{N}=45)\end{array}$ & $\begin{array}{l}\text { FSM4 } \\
(\mathrm{N}=28)\end{array}$ & $\begin{array}{l}\text { FSM5 } \\
(\mathrm{N}=17)\end{array}$ & $\begin{array}{l}\text { FSM6 } \\
(\mathrm{N}=33)\end{array}$ \\
\hline \multicolumn{7}{|l|}{ Farmland share } \\
\hline Share of private UAA in total land area & $0.24[0.07]$ & $0.09[0.07]$ & $0.08[0.05]$ & $0.19[0.09]$ & $0.19[0.11]$ & $0.25[0.09]$ \\
\hline \multicolumn{7}{|l|}{ Agricultural intensity } \\
\hline \multirow[t]{2}{*}{ Average standard output $(€)$ per hectare of total land } & 407.76 & 142.63 & 146.13 & 353.91 & 505.85 & 213.07 \\
\hline & {$[115.00]$} & {$[77.10]$} & {$[70.10]$} & {$[254.00]$} & {$[326.00]$} & {$[70.60]$} \\
\hline Share of irrigable area in total land area & $0.18[0.09]$ & $0.04[0.04]$ & $0.06[0.04]$ & $0.16[0.09]$ & $0.13[0.07]$ & $0.11[0.08]$ \\
\hline Average grazing LU per hectare of total land & $0.12[0.07]$ & $0.12[0.09]$ & $0.12[0.07]$ & $0.18[0.13]$ & $0.10[0.09]$ & $0.14[0.06]$ \\
\hline \multicolumn{7}{|l|}{ Livestock composition } \\
\hline Share of cattle in total grazing LU & $0.67[0.11]$ & $0.40[0.12]$ & $0.58[0.20]$ & $0.66[0.19]$ & $0.29[0.21]$ & $0.73[0.21]$ \\
\hline Share of sheep in total grazing LU & $0.18[0.10]$ & $0.03[0.05]$ & $0.17[0.15]$ & $0.16[0.13]$ & $0.44[0.20]$ & $0.10[0.10]$ \\
\hline Share of goats in total grazing LU & $0.03[0.03]$ & $0.46[0.11]$ & $0.08[0.08]$ & $0.07[0.08]$ & $0.15[0.12]$ & $0.05[0.06]$ \\
\hline \multicolumn{7}{|l|}{ Agricultural land use } \\
\hline Share of arable land & $0.16[0.04]$ & $0.04[0.03]$ & $0.04[0.03]$ & $0.09[0.05]$ & $0.05[0.04]$ & $0.06[0.04]$ \\
\hline Share of permanent pastures in commons & $0.01[0.04]$ & $0.18[0.16]$ & $0.32[0.34]$ & $0.07[0.13]$ & $0.18[0.38]$ & $0.41[0.24]$ \\
\hline Share of permanent pastures in private land (lameiros) & $0.02[0.02]$ & $0.05[0.07]$ & $0.03[0.02]$ & $0.06[0.04]$ & $0.03[0.04]$ & $0.18[0.08]$ \\
\hline Share of permanent crops & $0.04[0.02]$ & $0.00[0.00]$ & $0.01[0.01]$ & $0.03[0.02]$ & $0.11[0.07]$ & $0.00[0.01]$ \\
\hline Share of kitchen garden & $0.01[0.00]$ & $0.00[0.00]$ & $0.00[0.00]$ & $0.01[0.00]$ & $0.00[0.00]$ & $0.00[0.00]$ \\
\hline Share of fallow land & $0.02[0.01]$ & $0.00[0.00]$ & $0.00[0.00]$ & $0.00[0.00]$ & $0.01[0.01]$ & $0.00[0.00]$ \\
\hline Share of rye & $0.00[0.00]$ & $0.00[0.00]$ & $0.00[0.00]$ & $0.00[0.00]$ & $0.00[0.00]$ & $0.02[0.02]$ \\
\hline Share of maize & $0.06[0.01]$ & $0.01[0.01]$ & $0.01[0.01]$ & $0.04[0.02]$ & $0.02[0.01]$ & $0.02[0.01]$ \\
\hline Share of potato & $0.00[0.00]$ & $0.00[0.00]$ & $0.00[0.01]$ & $0.01[0.00]$ & $0.00[0.00]$ & $0.01[0.00]$ \\
\hline Share of annual fodder crops & $0.07[0.05]$ & $0.01[0.01]$ & $0.01[0.01]$ & $0.06[0.04]$ & $0.02[0.02]$ & $0.03[0.03]$ \\
\hline \multicolumn{7}{|l|}{ Farm specialization pattern } \\
\hline Share of private UAA used by farms specialized in field crops & $0.05[0.06]$ & $0.04[0.06]$ & $0.04[0.05]$ & $0.02[0.05]$ & $0.00[0.01]$ & $0.20[0.08]$ \\
\hline Share of private UAA used by farms specialized in wine & $0.08[0.09]$ & $0.01[0.02]$ & $0.02[0.04]$ & $0.06[0.05]$ & $0.47[0.22]$ & $0.00[0.00]$ \\
\hline Share of private UAA used by farms specialized in cattle & $0.09[0.11]$ & $0.43[0.28]$ & $0.29[0.22]$ & $0.09[0.11]$ & $0.02[0.05]$ & $0.39[0.23]$ \\
\hline Share of private UAA used by farms specialized in sheep & $0.03[0.06]$ & $0.03[0.03]$ & $0.07[0.08]$ & $0.01[0.02]$ & $0.03[0.06]$ & $0.03[0.04]$ \\
\hline Share of private UAA used by farms specialized in goats & $0.01[0.01]$ & $0.23[0.17]$ & $0.02[0.03]$ & $0.02[0.03]$ & $0.01[0.03]$ & $0.02[0.02]$ \\
\hline Share of private UAA used by mixed livestock farms & $0.20[0.11]$ & $0.11[0.06]$ & $0.31[0.14]$ & $0.22[0.18]$ & $0.10[0.08]$ & $0.12[0.07]$ \\
\hline Share of private UAA used by farms combining annual and permanent crops & $0.15[0.09]$ & $0.04[0.05]$ & $0.04[0.05]$ & $0.12[0.13]$ & $0.07[0.05]$ & $0.03[0.09]$ \\
\hline $\begin{array}{l}\text { Share of private UAA used by mixed livestock farms, mainly granivores and gr- } \\
\text { azing livestock }\end{array}$ & $0.03[0.05]$ & $0.00[0.01]$ & $0.03[0.05]$ & $0.05[0.05]$ & $0.01[0.05]$ & $0.15[0.14]$ \\
\hline Share of private UAA used by farms combining permanent/various crops and & $0.27[0.12]$ & $0.07[0.10]$ & $0.12[0.11]$ & $0.38[0.20]$ & $0.23[0.15]$ & $0.04[0.06]$ \\
\hline
\end{tabular}


Appendix D. Histogram first linear discriminant axis (LD1) for the Complete model.
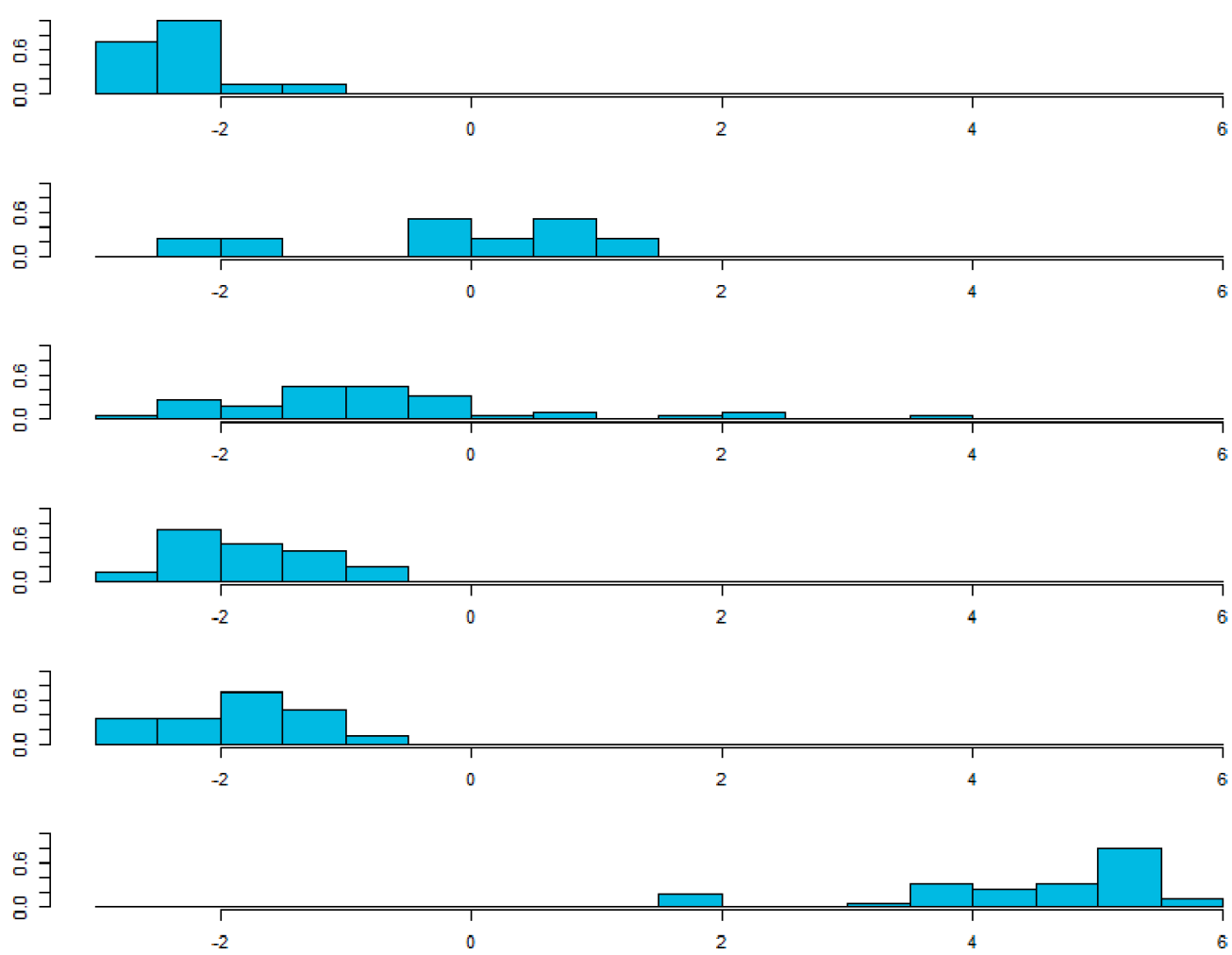

Appendix E. Histogram of second linear discriminant axis (LD2) for the Complete model.
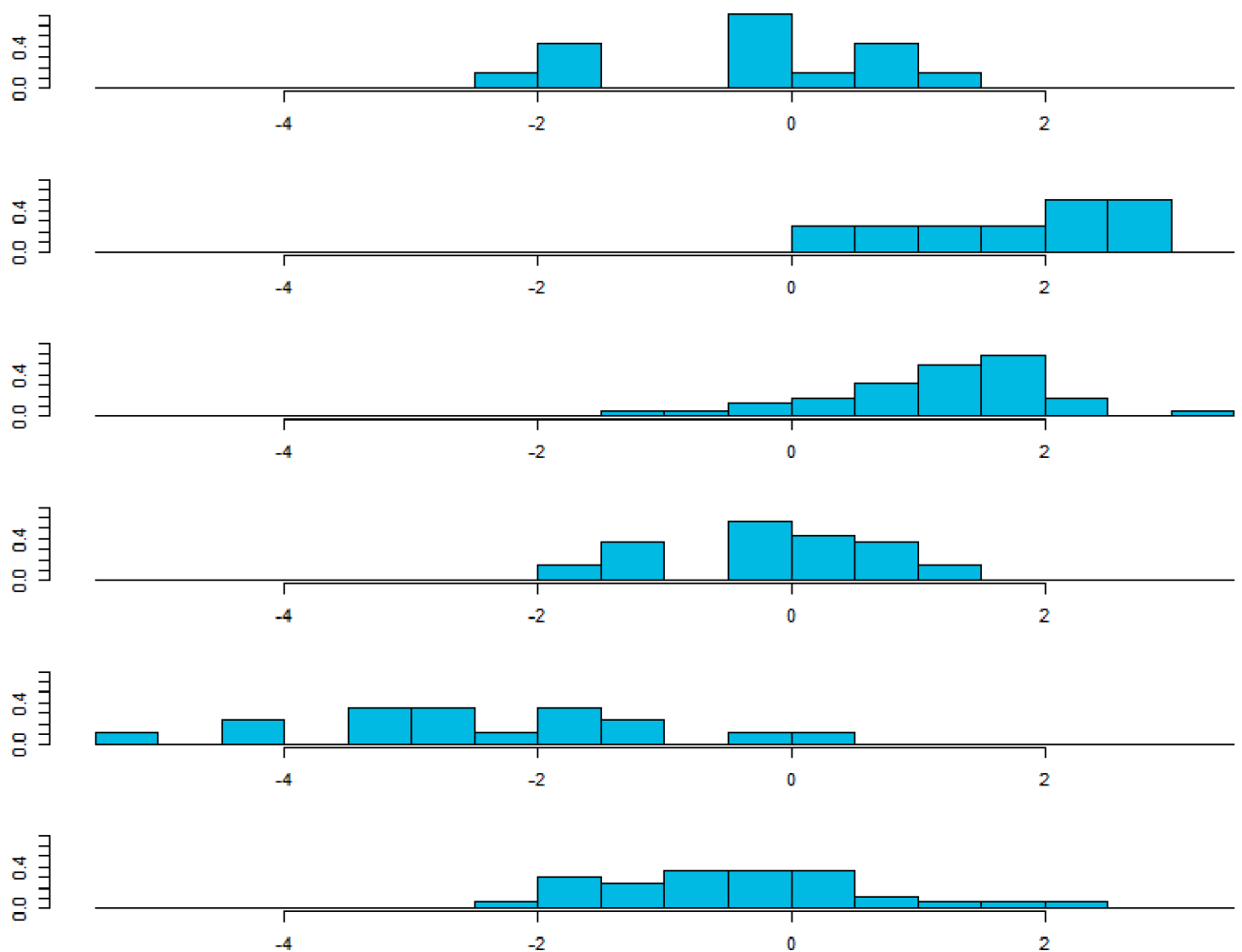
Appendix F. Histogram of third linear discriminant axis (LD3) for the Complete model.
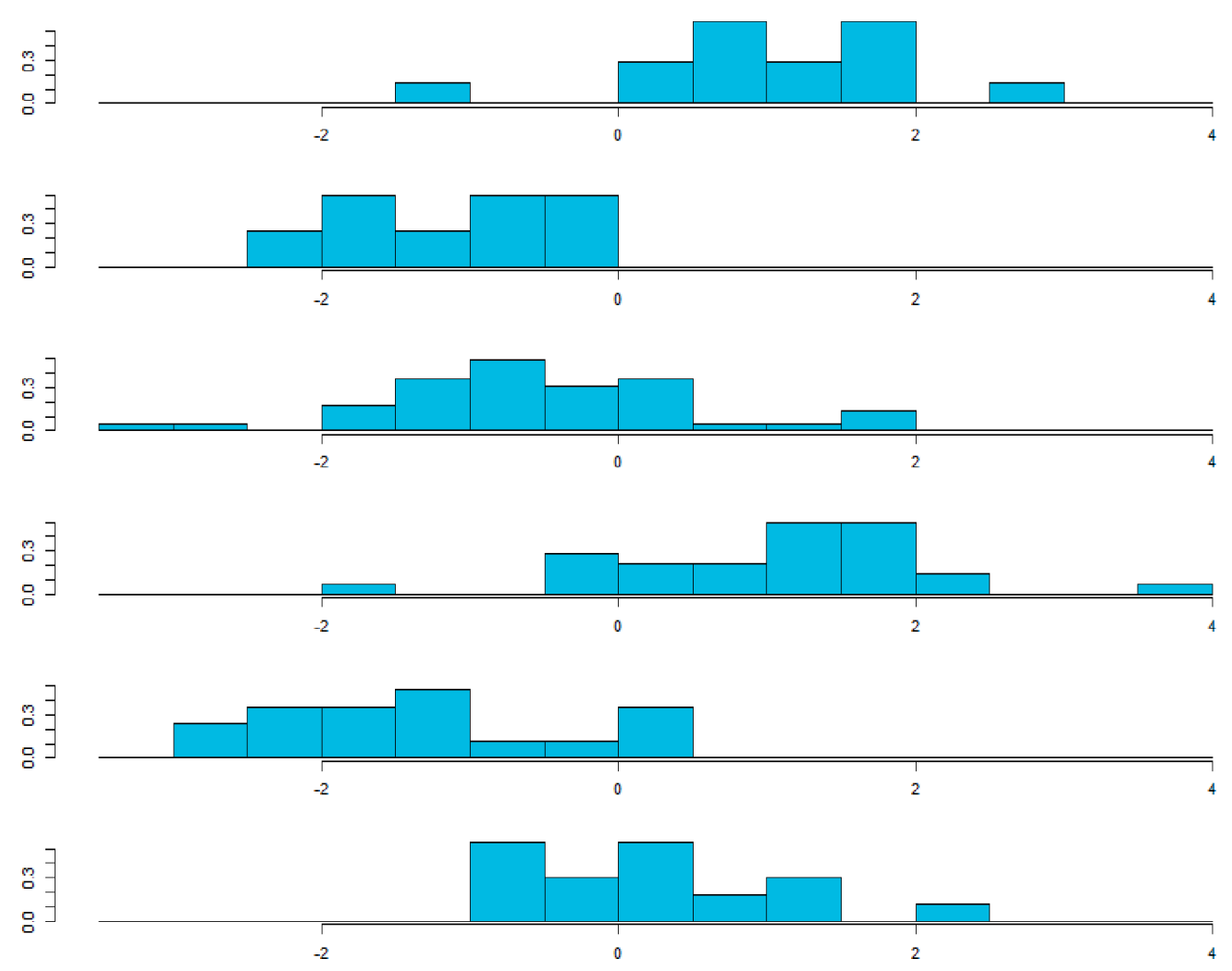

Appendix G. Histogram first linear discriminant axis (LD1) for the biophysical model.
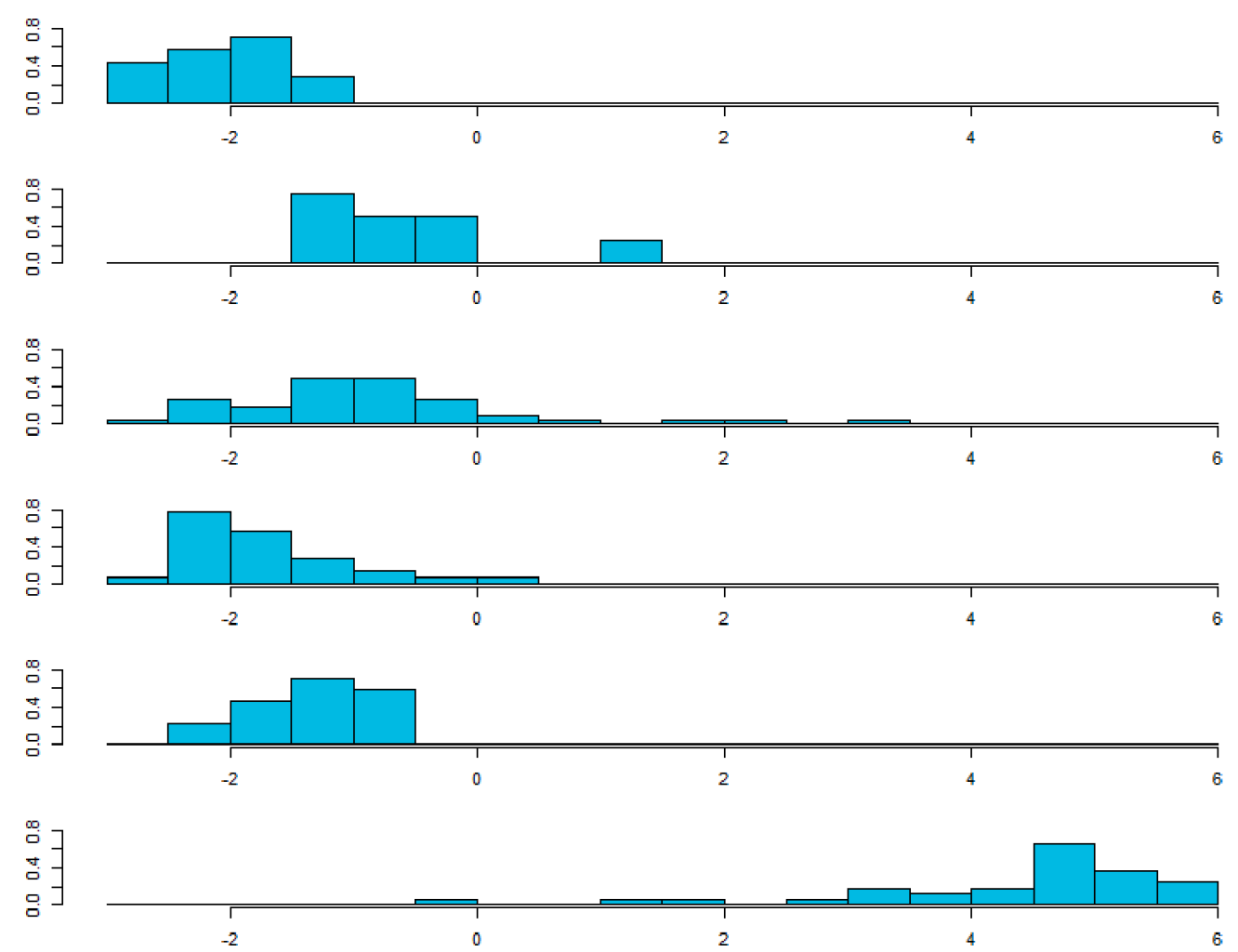
Appendix H. Histogram of second linear discriminant axis (LD2) for the biophysical model.
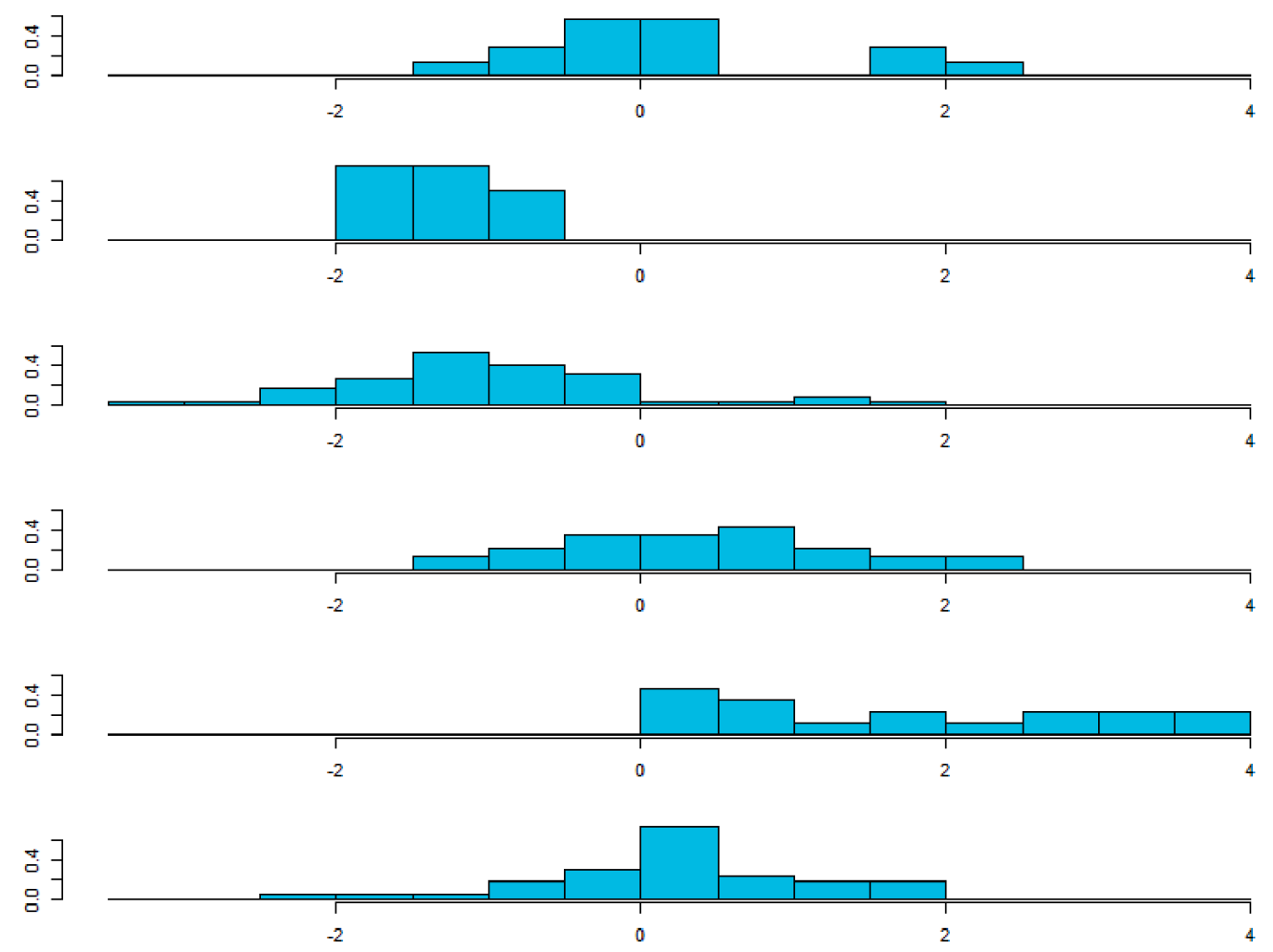

Appendix I. Histogram of third linear discriminant axis (LD3) for the biophysical model.
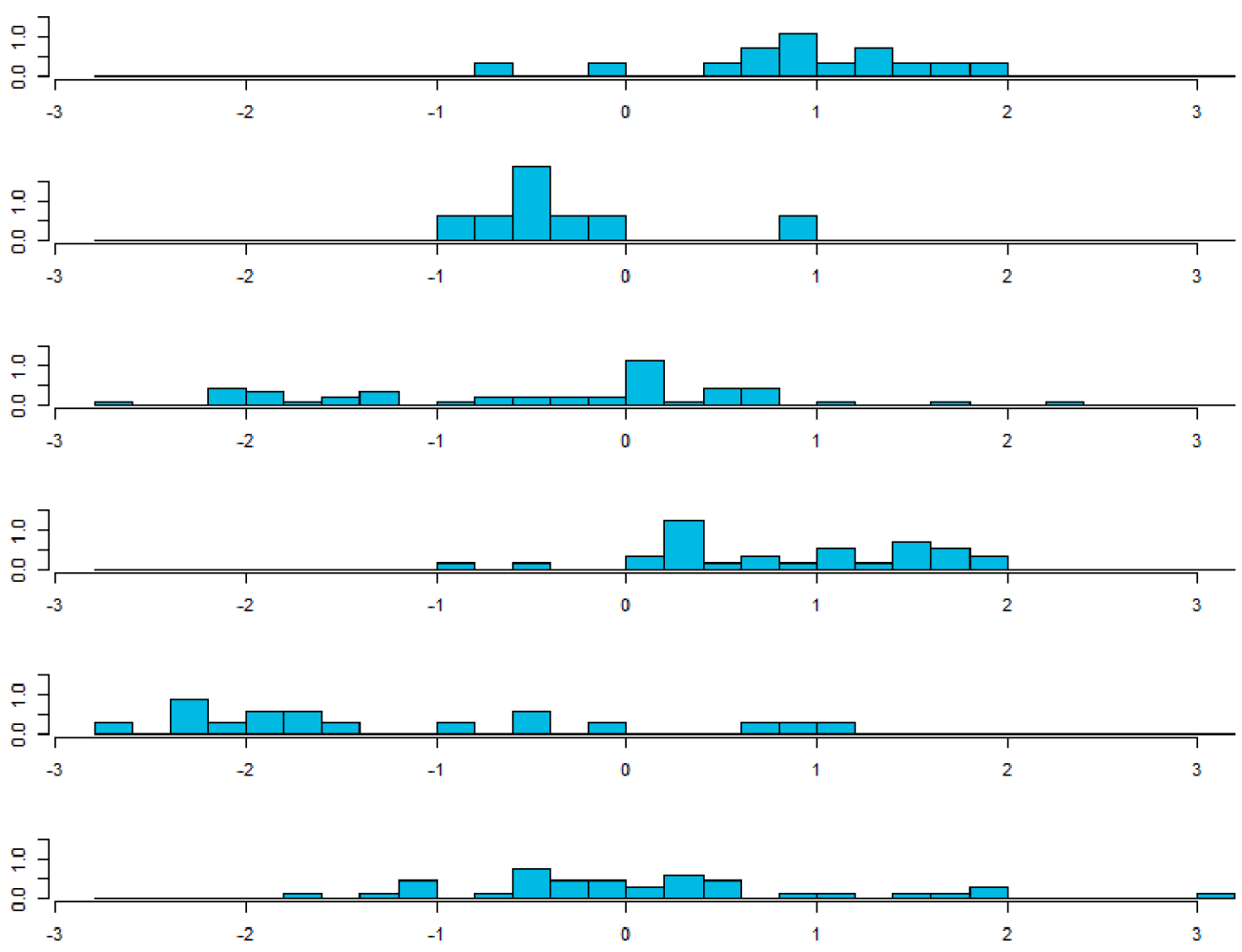
Appendix J. Confusion matrix comparing LDA predictions based on biophysical and socioeconomic factors with the observed FSM classifications.

Predicted
Total Correctly

assigned

(\%)

\begin{tabular}{|c|c|c|c|c|c|c|c|c|c|}
\hline & $\begin{array}{l}\text { Farming System Mixes } \\
\text { (FSM) }\end{array}$ & $\begin{array}{l}\text { FSM1: } \\
\text { Intensive mul- } \\
\text { tiple crop and } \\
\text { cattle farming } \\
\text { based on } \\
\text { arable land }\end{array}$ & $\begin{array}{l}\text { FSM2: Residual } \\
\text { farmland; spe- } \\
\text { cialized cattle } \\
\text { and goat } \\
\text { grazing in } \\
\text { common land }\end{array}$ & $\begin{array}{l}\text { FSM3: Residual } \\
\text { farmland }+ \text { grazing } \\
\text { of mixed livestock } \\
\text { and specialized cattle } \\
\text { in common land }\end{array}$ & $\begin{array}{l}\text { FSM4: } \\
\text { Intensive } \\
\text { cattle and } \\
\text { multiple crop } \\
\text { farming based } \\
\text { on arable land }\end{array}$ & $\begin{array}{l}\text { FSM5: Intensive specia- } \\
\text { lized wine }+ \text { mixed } \\
\text { crops and livestock } \\
\text { (sheep) based on private } \\
\text { farmland and common } \\
\text { pastures }\end{array}$ & $\begin{array}{l}\text { FSM16: Low-in- } \\
\text { tensity specialized } \\
\text { cattle grazing } \\
\text { based on } \\
\text { (common and pri- } \\
\text { vate) pastures }\end{array}$ & & \\
\hline \multirow[t]{7}{*}{ Observed } & $\begin{array}{l}\text { FSM1: Intensive mul- } \\
\text { tiple crop and cattle } \\
\text { farming based on arable } \\
\text { land }\end{array}$ & 5 & 1 & 0 & 8 & 0 & 0 & 14 & 35.7 \\
\hline & $\begin{array}{l}\text { FSM2: Residual farm- } \\
\text { land; specialized cattle } \\
\text { and goat grazing in } \\
\text { common land }\end{array}$ & 0 & 2 & 5 & 0 & 1 & 0 & 8 & 25.0 \\
\hline & $\begin{array}{l}\text { FSM3: Residual } \\
\text { farmland + grazing of } \\
\text { mixed livestock and } \\
\text { specialized cattle in } \\
\text { common land }\end{array}$ & 0 & 3 & 32 & 7 & 1 & 2 & 45 & 71.1 \\
\hline & $\begin{array}{l}\text { FSM4: Intensive cattle } \\
\text { and multiple crop } \\
\text { farming based on arable } \\
\text { land }\end{array}$ & 4 & 0 & 4 & 19 & 1 & 0 & 28 & 67.9 \\
\hline & $\begin{array}{l}\text { FSM5: Intensive specia- } \\
\text { lized wine }+ \text { mixed } \\
\text { crops and livestock } \\
\text { (sheep) based on private } \\
\text { farmland and common } \\
\text { pastures }\end{array}$ & $\underline{0}$ & 0 & 1 & 3 & 13 & 0 & 17 & 76.5 \\
\hline & $\begin{array}{l}\text { FSM16: Low-intensity } \\
\text { specialized cattle } \\
\text { grazing based on } \\
\text { (common and private) } \\
\text { pastures }\end{array}$ & 0 & 0 & 2 & 0 & 0 & 31 & 33 & 93.9 \\
\hline & Total & 9 & 6 & 44 & 37 & 16 & 33 & 145 & \\
\hline
\end{tabular}

Appendix K. Confusion matrix comparing LDA predictions based on biophysical factors with the observed FSM classifications.

Predicted
Total Correctly assigned

(\%)

Farming System Mixes (FSM)

FSM1:

Intensive mul- farm tiple crop and cialized cattle cattle farming and goat

based on grazing in arable land common land

Observed FSM1: Intensive mul$0 \quad 1$

tiple crop and cattle

farming based on arable

land

FSM2: Residual farm-

land; specialized cattle

and goat grazing in

common land

FSM3: Residual

farmland + grazing of

mixed livestock and

specialized cattle in

common land

FSM4: Intensive cattle

and multiple crop

farming based on arable

land and specialized cattle multiple crop
FSM2: Residual FSM3: Residual

FSM4:

farmland + grazing Intensive in common land

1

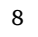

31

1

0

5

20 farming based on arable land

$$
12
$$

0

0

8

1

3

0

1

0

5

\section{of mixed livestock}

FSM5: Intensive specialized wine + mixed crops and livestock (sheep) based on private farmland and common

2 SM16: Low-intensity specialized cattle grazing based on

(common and private) pastures

0 14

0.0

0

8
9
0
28

71.4
45

68.9 
FSM5: Intensive specia-

lized wine + mixed

crops and livestock

(sheep) based on private

farmland and common

pastures

FSM16: Low-intensity

specialized cattle

grazing based on

(common and private)

pastures

Total

4

0

51

45

11

32

145

Appendix L. Biophysical factors potentially explaining the spatial distribution of FSM. SD $=$ Standard deviation. Note: $* * *, * *, *=\mathbf{p}$ value $<0.001,0.01,0.05$.

\begin{tabular}{|c|c|c|c|c|c|c|}
\hline \multirow[t]{2}{*}{ Description } & FSM1 & FSM2 & FSM3 & FSM4 & FSM5 & FSM6 \\
\hline & Mean $[S D]$ & Mean [SD] & Mean $[S D]$ & Mean [SD] & Mean [SD] & Mean $[S D]$ \\
\hline Elevation range (difference between the highest and the lowest point of the & 405.03 & 689.42 & 780.61 & 385.44 & 455.62 & 507.42 \\
\hline parish $)(\mathrm{m}) * * *$ & {$[157.55]$} & [131.68] & [309.83] & {$[175.75]$} & [304.15] & [198.21] \\
\hline Share of total land area with slopes between 0 and $12 \% * * *$ & $0.18[0.16]$ & $0.09[0.04]$ & $0.12[0.07]$ & $0.24[0.13]$ & $0.28[0.18]$ & $0.29[0.15]$ \\
\hline Share of total land area with slopes between 12 and $25 \% * * *$ & $0.33[0.07]$ & $0.26[0.07]$ & $0.29[0.08]$ & $0.35[0.08]$ & $0.34[0.05]$ & $0.38[0.07]$ \\
\hline Share of total land area with slopes greater than $25 \%$ *** & $0.49[0.22]$ & $0.65[0.10]$ & $0.59[0.14]$ & $0.41[0.17]$ & $0.38[0.19]$ & $0.33[0.18]$ \\
\hline Share of total land area with flat areas $* *$ & $0.00[0.00]$ & $0.00[0.00]$ & $0.00[0.00]$ & $0.00[0.00]$ & $0.00[0.00]$ & $0.00[0.00]$ \\
\hline Share of total land area with North facing slopes & $0.23[0.18]$ & $0.19[0.12]$ & $0.24[0.15]$ & $0.23[0.15]$ & $0.30[0.20]$ & $0.20[0.10]$ \\
\hline Share of total land area with East facing slopes * & $0.29[0.17]$ & $0.22[0.12]$ & $0.26[0.15]$ & $0.26[0.18]$ & $0.15[0.17]$ & $0.27[0.11]$ \\
\hline Share of total land area with South facing slope & $0.25[0.20]$ & $0.32[0.14]$ & $0.22[0.14]$ & $0.23[0.17]$ & $0.16[0.16]$ & $0.25[0.09]$ \\
\hline Share of total land area with West facing slopes & $0.23[0.16]$ & $0.26[0.10]$ & $0.28[0.13]$ & $0.28[0.19]$ & $0.39[0.17]$ & $0.28[0.12]$ \\
\hline Share of total land area with soil depth between 0 and $25 \mathrm{~cm} * * *$ & $0.00[0.00]$ & $0.14[0.21]$ & $0.11[0.22]$ & $0.00[0.00]$ & $0.01[0.03]$ & $0.01[0.03]$ \\
\hline Share of total land area with soil depth between 25 and $50 \mathrm{~cm} * * *$ & $0.47[0.28]$ & $0.85[0.21]$ & $0.67[0.23]$ & $0.46[0.24]$ & $0.49[0.17]$ & $0.78[0.12]$ \\
\hline Share of total land area with soil depth greater than $50 \mathrm{~cm} * * *$ & $0.53[0.28]$ & $0.02[0.02]$ & $0.22[0.22]$ & $0.54[0.24]$ & $0.50[0.18]$ & $0.22[0.12]$ \\
\hline Share of total land area with medium soil texture $* * *$ & $0.01[0.00]$ & $0.01[0.00]$ & $0.01[0.00]$ & $0.01[0.00]$ & $0.01[0.00]$ & $0.01[0.00]$ \\
\hline Share of total land area with coarse soil texture $* * *$ & $1.00[0.00]$ & $1.00[0.00]$ & $0.94[0.17]$ & $1.00[0.01]$ & $0.97[0.09]$ & $0.72[0.31]$ \\
\hline Share of total land area with soil $\mathrm{pH} 0-5 * * *$ & $0.96[0.08]$ & $0.99[0.02]$ & $0.87[0.24]$ & $0.86[0.20]$ & $0.92[0.09]$ & $0.55[0.32]$ \\
\hline Share of total land area with soil $\mathrm{pH} 5-6 * * *$ & $0.04[0.07]$ & $0.01[0.02]$ & $0.13[0.24]$ & $0.14[0.20]$ & $0.08[0.09]$ & $0.44[0.32]$ \\
\hline Share of total land area with soil $\mathrm{pH} 6-7$ & $0.00[0.00]$ & $0.00[0.00]$ & $0.00[0.00]$ & $0.00[0.00]$ & $0.00[0.00]$ & $0.00[0.01]$ \\
\hline \multirow[t]{2}{*}{ Average annual precipitation $* * *$} & 1458.51 & 1427.32 & 1467.54 & 1441.81 & 1366.37 & 1306.59 \\
\hline & [33.21] & {$[22.57]$} & [66.47] & [32.46] & [81.30] & [50.81] \\
\hline Average minimum temperature of the coldest month $* * *$ & $2.68[0.36]$ & $1.21[0.57]$ & $1.41[0.98]$ & $2.45[0.50]$ & $2.51[0.43]$ & $-0.93[0.68]$ \\
\hline Average maximum temperature of the warmest month $* * *$ & $24.31[0.36]$ & $23.40[0.94]$ & $22.80[1.42]$ & $24.43[0.52]$ & $24.04[1.30]$ & $21.53[1.12]$ \\
\hline Average annual temperature $* * *$ & $14.01[0.37]$ & $12.81[0.87]$ & $12.57[1.18]$ & $14.06[0.49]$ & $13.85[0.91]$ & $10.73[0.81]$ \\
\hline Average annual thermal amplitude ** & $21.63[0.34]$ & $22.19[0.46]$ & $21.39[1.06]$ & $21.98[0.44]$ & $21.53[0.95]$ & $22.46[1.05]$ \\
\hline Maximum average annual temperature within the parish $* * *$ & $14.53[0.14]$ & $13.95[0.69]$ & $14.01[0.83]$ & $14.56[0.23]$ & $14.50[0.34]$ & $11.76[1.02]$ \\
\hline
\end{tabular}

Appendix M. Socioeconomic factors potentially explaining the spatial distribution of FSM. SD = Standard deviation. UAA = Utilized agricultural Area. AWU $=$ annual work unit. Note: $* * *, * *, *=$ p value $<0.001,0.01,0.05$.

\begin{tabular}{|c|c|c|c|c|c|c|}
\hline Description & $\begin{array}{l}\text { FSM1 } \\
\text { Mean [SD] }\end{array}$ & $\begin{array}{l}\text { FSM2 } \\
\text { Mean [SD] }\end{array}$ & $\begin{array}{l}\text { FSM3 } \\
\text { Mean [SD] }\end{array}$ & $\begin{array}{l}\text { FSM4 } \\
\text { Mean [SD] }\end{array}$ & $\begin{array}{l}\text { FSM5 } \\
\text { Mean [SD] }\end{array}$ & $\begin{array}{l}\text { FSM6 } \\
\text { Mean [SD] }\end{array}$ \\
\hline Share of farms $<5$ ha in total UAA $* * *$ & $0.83[0.12]$ & $0.25[0.27]$ & $0.31[0.28]$ & $0.71[0.27]$ & $0.54[0.30]$ & $0.09[0.10]$ \\
\hline Share of farms $5-50$ ha in total UAA $* * *$ & $0.14[0.09]$ & $0.31[0.25]$ & $0.13[0.20]$ & $0.19[0.20]$ & $0.24[0.24]$ & $0.35[0.20]$ \\
\hline Share of farms greater than 50 ha in total UAA *** & $0.03[0.11]$ & $0.44[0.40]$ & $0.56[0.39]$ & $0.10[0.26]$ & $0.22[0.36]$ & $0.57[0.22]$ \\
\hline Average number of blocks per holding $* * *$ & $5.20[1.01]$ & $6.95[4.71]$ & $8.23[5.10]$ & $4.77[1.48]$ & $4.54[2.01]$ & $18.70[6.39]$ \\
\hline Average private UAA per block * & $0.42[0.12]$ & $1.22[1.99]$ & $0.46[0.66]$ & $0.43[0.16]$ & $0.52[0.50]$ & $0.46[0.23]$ \\
\hline Share of common land in total UAA *** & $0.04[0.11]$ & $0.54[0.34]$ & $0.60[0.35]$ & $0.18[0.28]$ & $0.27[0.35]$ & $0.57[0.22]$ \\
\hline \multirow[t]{2}{*}{ Population density per $\mathrm{km}^{2} * * *$} & 121.17 & 20.66 & 38.11 & 239.47 & 181.86 & 13.44 \\
\hline & [46.98] & [15.93] & [34.24] & [472.74] & {$[186.34]$} & [14.88] \\
\hline Share of elderly population in resident population $* * *$ & $0.26[0.05]$ & $0.37[0.11]$ & $0.37[0.10]$ & $0.28[0.07]$ & $0.31[0.09]$ & $0.38[0.07]$ \\
\hline Share of working age population in resident population $* * *$ & $0.61[0.04]$ & $0.54[0.07]$ & $0.54[0.08]$ & $0.60[0.05]$ & $0.58[0.06]$ & $0.54[0.05]$ \\
\hline Share of non-family labour in total AWU *** & $0.05[0.03]$ & $0.03[0.02]$ & $0.03[0.03]$ & $0.04[0.04]$ & $0.11[0.08]$ & $0.03[0.02]$ \\
\hline Average agricultural workers per AWU ** & $0.08[0.06]$ & $0.23[0.14]$ & $0.11[0.11]$ & $0.13[0.14]$ & $0.12[0.08]$ & $0.16[0.09]$ \\
\hline Average number of farm household members per hectare of private UAA *** & $1.58[0.29]$ & $1.28[1.16]$ & $1.47[0.60]$ & $1.60[0.45]$ & $1.95[0.69]$ & $0.36[0.16]$ \\
\hline Average number of farm household members per total holdings $* * *$ & $3.19[0.37]$ & $2.83[0.40]$ & $2.73[0.39]$ & $2.82[0.39]$ & $2.80[0.25]$ & $2.44[0.20]$ \\
\hline $\begin{array}{l}\text { Share of holdings whose income is exclusively or mainly from agricultural activity in } \\
\text { the holding *** }\end{array}$ & $0.13[0.10]$ & $0.28[0.16]$ & $0.16[0.15]$ & $0.07[0.08]$ & $0.09[0.10]$ & $0.39[0.16]$ \\
\hline Share of holdings whose income is mainly from retirement pensions $* * *$ & $0.67[0.13]$ & $0.52[0.17]$ & $0.67[0.14]$ & $0.70[0.14]$ & $0.68[0.12]$ & $0.49[0.15]$ \\
\hline Share of holdings whose income is mainly from other external sources $* * *$ & $0.20[0.06]$ & $0.20[0.09]$ & $0.17[0.11]$ & $0.23[0.12]$ & $0.24[0.07]$ & $0.12[0.07]$ \\
\hline $\begin{array}{l}\text { Share of holdings whose household consumes more than } 50 \% \text { of the final production } \\
* *\end{array}$ & $0.33[0.31]$ & $0.10[0.13]$ & $0.15[0.20]$ & $0.14[0.25]$ & 0.09 [0.13] & $0.06[0.16]$ \\
\hline Share of farmers with none level of education * & $0.32[0.14]$ & $0.26[0.18]$ & $0.34[0.16]$ & $0.34[0.13]$ & $0.20[0.16]$ & $0.33[0.13]$ \\
\hline Share of farmers with basic level of education & $0.61[0.12]$ & $0.70[0.19]$ & $0.64[0.16]$ & $0.63[0.13]$ & $0.67[0.18]$ & $0.62[0.13]$ \\
\hline Share of farmers with higher level of education $* * *$ & $0.07[0.06]$ & $0.04[0.04]$ & $0.02[0.04]$ & $0.04[0.03]$ & $0.13[0.09]$ & $0.05[0.04]$ \\
\hline Share of farmers aged between 15 and 44 years & $0.10[0.06]$ & $0.15[0.10]$ & $0.11[0.09]$ & $0.10[0.08]$ & $0.08[0.04]$ & $0.13[0.07]$ \\
\hline Share of farmers aged between 45 and 64 years & $0.45[0.11]$ & $0.47[0.17]$ & $0.48[0.13]$ & $0.47[0.11]$ & $0.43[0.11]$ & $0.41[0.10]$ \\
\hline Share of farmers aged more than 65 years & $0.45[0.12]$ & $0.38[0.14]$ & $0.42[0.11]$ & $0.42[0.10]$ & $0.48[0.10]$ & $0.47[0.12]$ \\
\hline
\end{tabular}


Share of total employed population in primary sector *** Share of total employed population in manufacturing, energy and water $* * *$ Share of total employed population in construction *** Proportion of total employed population in private services * Share of total employed population in public services ** Share of total employed population in other activities $* * *$
$0.08[0.04]$

$0.16[0.07]$

$0.20[0.09]$

$0.29[0.10]$

$0.21[0.09]$

$0.05[0.04]$

$\begin{array}{lll}0.23[0.20] & 0.14[0.13] & 0.08[0.06] \\ 0.09[0.10] & 0.13[0.07] & 0.18[0.06] \\ 0.19[0.09] & 0.20[0.07] & 0.20[0.09] \\ 0.22[0.10] & 0.29[0.09] & 0.28[0.06] \\ 0.20[0.07] & 0.19[0.08] & 0.20[0.08] \\ 0.06[0.06] & 0.05[0.04] & 0.05[0.03]\end{array}$

0.07 [0.05]

0.13 [0.07]

$0.14[0.06]$

0.31 [0.07]

0.29 [0.09]

0.06 [0.02]
0.33 [0.17]

0.08 [0.07]

$0.13[0.09]$

0.24 [0.09]

0.19 [0.10]

0.03 [0.04]

\section{Appendix N. Supplementary data}

Supplementary data to this article can be found online at https://doi.org/10.1016/j.landurbplan.2020.103879.

\section{References}

Agroconsultores, \& Coba. (1991). Carta de Solos, Carta do Uso Actual da Terra e Carta da Aptidão da Terra do Nordeste de Portugal. Escala 1/100000. Vila Real: UTAD.

Agroconsultores, \& Geometral. (1995). Carta dos Solos e Carta da Aptidão da Terra de Entre-Douro e Minho. Escala 1/100000. Braga: DRAEDM.

Alvarez, S., Paas, W., Descheemaeker, K., Tittonell, P., \& Groot, J. (2014). Typology construction, a way of dealing with farm diversity General guidelines for Humidtropics. Report for the. CGIAR Research Program on Integrated Systems for the Humid Tropics., Plant Scie (pp. 1-37). .

Andersen, E. (2017). The farming system component of European agricultural landscapes. European Journal of Agronomy, 82, 282-291. https://doi.org/10.1016/j.eja.2016.09. 011.

Baptista, F. O. (2010). O Espaço Rural. Declínio da Agricultura. (Celta Editora, Ed.) (1st ed.). Lisboa.

Bhatta, G. D., \& Doppler, W. (2011). Spatial Distribution of Farm-Family Resources in the Mid-Hills of Nepal. Asian Journal of Agriculture and Development, 8(2), 43-59 Retrieved from http://searca.org/ajad/read-articles/13-view-article?aid=101.

Bignal, E., \& McCracken, D. (2000). The nature conservation value of European traditional farming systems. Environmental Reviews, 8(3), 149-171. https://doi.org/10. 1139/er-8-3-149.

Budiharta, S., Meijaard, E., Wells, J. A., Abram, N. K., \& Wilson, K. A. (2016). Enhancing feasibility: Incorporating a socio-ecological systems framework into restoration planning. Environmental Science and Policy, 64, 83-92. https://doi.org/10.1016/j. envsci.2016.06.014.

Calvo-Iglesias, M. S., Fra-Paleo, U., \& Diaz-Varela, R. A. (2009). Changes in farming system and population as drivers of land cover and landscape dynamics: The case of enclosed and semi-openfield systems in Northern Galicia (Spain). Landscape and Urban Planning, 90(3-4), 168-177. https://doi.org/10.1016/j.landurbplan.2008.10. 025.

Dang, A. N., \& Kawasaki, A. (2017). Integrating biophysical and socio-economic factors for land-use and land-cover change projection in agricultural economic regions. Ecological Modelling, 344, 29-37. https://doi.org/10.1016/j.ecolmodel.2016.11.004.

Dixon, J., Gulliver, A., \& Gibbon, D. (2001). Farming Systems and poverty: improving farmers' livelihoods in a changing world. (M. Hall, Ed.). Rome and Washington D.C.: FAO and World Bank. Doi: 10.1017/S0014479702211059.

Elsheikh, R., Mohamed Shariff, A. R. B., Amiri, F., Ahmad, N. B., Balasundram, S. K., \& Soom, M. A. M. (2013). Agriculture Land Suitability Evaluator (ALSE): A decision and planning support tool for tropical and subtropical crops. Computers and Electronics in Agriculture, 93, 98-110. https://doi.org/10.1016/j.compag.2013.02.003.

ESRI. (2016). ArcGIS 10.5. Redlands, CA: Environmental Systems Research Institute. Retrieved from https://www.esri.com/en-us/home.

Fick, S. E., \& Hijmans, R. J. (2017). WorldClim 2: New 1-km spatial resolution climate surfaces for global land areas. International Journal of Climatology, 37(12), 4302-4315. https://doi.org/10.1002/joc.5086.

Friendly, M., \& Fox, J. (2017). candisc: Visualizing Generalized Canonical Discriminant and Canonical Correlation Analysis. R package version 0.8-0. Retrieved from https:// cran.r-project.org/package $=$ candisc.

Gil-Tena, A., De Cáceres, M., Ernoult, A., Butet, A., Brotons, L., \& Burel, F. (2015). Agricultural landscape composition as a driver of farmland bird diversity in Brittany (NW France). Agriculture, Ecosystems and Environment, 205, 79-89. https://doi.org/ 10.1016/j.agee.2015.03.013.

Hinojosa, L., Tasser, E., Rüdisser, J., Leitinger, G., Schermer, M., Lambin, E. F., \& Tappeiner, U. (2019). Geographical heterogeneity in mountain grasslands dynamics in the Austrian-Italian Tyrol region. Applied Geography, 106, 50-59. https://doi.org/ 10.1016/j.apgeog.2019.03.006.

Hird, V. (2017). Farming systems and techniques that promote biodiversity. Biodiversity, 18(2-3), 71-74. https://doi.org/10.1080/14888386.2017.1351395.

Hopkins, A. (2011). Mountainous farming in Europe. In E. M. Pötsch, B. Krautzer, \& A. Hopkins (Eds.), Grassland Farming and Land Management Systems in Mountainous Regions. (Vol. 16, pp. 3-12). Gumpenstein, Austria: Organising Committee of the 16th Symposium of the European Grassland Federation 2011 and Agricultura Research and Education Centre (AREC).

INAG (2010). Modelo Digital de Terreno de Portugal Continental (Digital Terrain Model). Lisboa: Instituto Nacional da Água, I. P. Agência Portuguesa Ambiente.

INE (2011). Censos 2011 Resultados Defnitivos - Portugal. (I. P. Instituto Nacional de Estatística, Ed.) (Vol. 60). Lisboa. Doi: 10.13541/j.cnki.chinade.2011.07.013.

INE (2011). Recenseamento Agrícola 2009 - Análise dos principais resultados. Lisboa.

Jel, Q., Carillo, F., Carillo, M. R., Venittelli, T., \& Zazzaro, A. (2013). Aging and

Succession on Italian Farms, 39-55.
Kaiser, H. (1960). The application of electronic computers to factor analysis. Educational and Psychological Measurement.

Kamkar, B., Dorri, M. A., \& Da Silva, J. A. T. (2014). Assessment of land suitability and the possibility and performance of a canola (Brassica napus L.) - Soybean (Glycine max L.) rotation in four basins of Golestan province, Iran. Egyptian Journal of Remote Sensing and Space Science, 17(1), 95-104. https://doi.org/10.1016/j.ejrs.2013.12. 001.

Kilic, S., Evrendilek, F., Senol, S., \& Celik, I. (2005). Developing a suitability index for land uses and agricultural land covers: A case study in Turkey. Environmental Monitoring and Assessment, 102(1-3), 323-335. https://doi.org/10.1007/s10661005-6030-6.

Kobrich, C., Rehman, T., \& Khan, M. (2003). Typification of farming systems for constructing representative farm models: Two illustrations of the application of multivariate analyses in Chile and Pakistan. Agricultural Systems, 76(1), 141-157. https:// doi.org/10.1016/S0308-521X(02)00013-6.

Lomba, A., Moreira, F., Klimek, S., Jongman, R. H. G., Sullivan, C., Moran, J., ... McCracken, D. I. (2020). Back to the future: Rethinking socioecological systems underlying high nature value farmlands. Frontiers in Ecology and the Environment, 18(1), 36-42. https://doi.org/10.1002/fee.2116.

MacDonald, D., Crabtree, J. R., Wiesinger, G., Dax, T., Stamou, N., Fleury, P., ... Gibon, A. (2000). Agricultural abandonment in mountain areas of Europe: Environmental consequences and policy response. Journal of Environmental Management, 59(1), 47-69. https://doi.org/10.1006/jema.1999.0335.

Mądry, W., Roszkowska-Mądra, B., Gozdowski, D., \& Hryniewski, R. (2016). Some aspects of the Concept, Methodology and Application of Farming System Typology. Electronic Jounal of Polish Agricultural Universities, 19(1).

Moreira, F., Rego, F. C., \& Ferreira, P. G. (2001). Temporal (1958-1995) pattern of change in a cultural landscape of northwestern Portugal: Implications for fire occurrence. Landscape Ecology, 16(6), 557-567. https://doi.org/10.1023/ A: 1013130528470

Niemiec, R. M., Asner, G. P., Gaertner, J. A., Brodrick, P. G., Vaughn, N., Heckler, J., ... Matsumoto, T. (2019). Using spatially explicit, time-dependent analysis to understand how social factors influence conservation outcomes. Conservation Biology. https://doi.org/10.1111/cobi.13409.

Pereira, H., \& Navarro, L. (Eds.). (2015). Rewilding European Landscapes. Rewilding European Landscapes. Springer, Cham. Doi: 10.1007/978-3-319-12039-3 7.

Pfeifer, C., Jongeneel, R. A., Sonneveld, M. P. W., \& Stoorvogel, J. J. (2009). Landscape properties as drivers for farm diversification: A Dutch case study. Land Use Policy, 26(4), 1106-1115. https://doi.org/10.1016/j.landusepol.2009.01.007.

Pierpaoli, E., Carli, G., Pignatti, E., \& Canavari, M. (2013). Drivers of Precision Agriculture Technologies Adoption: A Literature Review. Procedia Technology, 8(Haicta), 61-69. https://doi.org/10.1016/j.protcy.2013.11.010.

Plieninger, T., Draux, H., Fagerholm, N., Bieling, C., Bürgi, M., Kizos, T., ... Verburg, P. H. (2016). The driving forces of landscape change in Europe: A systematic review of the evidence. Land Use Policy, 57, 204-214. https://doi.org/10.1016/j.landusepol.2016. 04.040.

Prokopy, L. S., Floress, K., Klotthor-Weinkauf, D., \& Baumgart-Getz, A. (2008). Determinants of agricultural best management practice adoption: Evidence from the literature. Journal of Soil and Water Conservation, 63(5), 300-311. https://doi.org/10. 2489/jswc.63.5.300.

R Core Team. (2017). R: A language and environment for statistical computing. Vienna, Austria: R Foundation for Statistical Computing. Retrieved from https://www.rproject.org/.

Reboul, C. (1976). Mode de production et systèmes de culture et d'élevage. Économie Rurale, 112(1), 55-65. https://doi.org/10.3406/ecoru.1976.2413.

Revelle, W. (2018). psych: Procedures for Personality and Psychological Research. Evanston, Illinois, USA,: Northwestern University. Retrieved from https://cran.rproject.org $/$ package $=$ psychVersion $=1.8 .4$.

Ribeiro, P. F., Nunes, L. C., Beja, P., Reino, L., Santana, J., Moreira, F., \& Santos, J. L. (2018). A Spatially Explicit Choice Model to Assess the Impact of Conservation Policy on High Nature Value Farming Systems. Ecological Economics, 145, 331-338. https:// doi.org/10.1016/j.ecolecon.2017.11.011.

Ribeiro, P. F., Santos, J. L., Bugalho, M. N., Santana, J., Reino, L., Beja, P., \& Moreira, F. (2014). Modelling farming system dynamics in High Nature Value Farmland under policy change. Agriculture, Ecosystems \& Environment, 183, 138-144. https://doi.org/ 10.1016/j.agee.2013.11.002.

Ribeiro, P. F., Santos, J. L., Santana, J., Reino, L., Beja, P., \& Moreira, F. (2016). An applied farming systems approach to infer conservation-relevant agricultural practices for agri-environment policy design. Land Use Policy, 58, 165-172. https://doi. org/10.1016/j.landusepol.2016.07.018.

Rizzo, D., Marraccini, E., Lardon, S., Rapey, H., Debolini, M., Benoît, M., \& Thenail, C. 
(2013). Farming systems designing landscapes: Land management units at the interface between agronomy and geography. Geografisk Tidsskrift, 113(2), 71-86. https://doi.org/10.1080/00167223.2013.849391.

Santana, J., Reino, L., Stoate, C., Moreira, F., Ribeiro, P. F., Santos, J. L., ... Beja, P. (2016). Combined effects of landscape composition and heterogeneity on farmland avian diversity. Ecology and Evolution, 7(4), 1212-1223. https://doi.org/10.1002/ ece3.2693.

Santos, J. L. (1992). Mercado, economias e ecossistemas no Alto Barroso. (Câmara Municipal de Montalegre, Ed.). Montalegre: Instituto Superior de Agronomia.

Stoate, C., Báldi, A., Beja, P., Boatman, N. D., Herzon, I., van Doorn, A., ... Ramwell, C. (2009). Ecological impacts of early 21st century agricultural change in Europe - A review. Journal of Environmental Management, 91(1), 22-46. https://doi.org/10. 1016/j.jenvman.2009.07.005.

Stoate, C., Boatman, N. D., Borralho, R. J., Carvalho, C. R., De Snoo, G. R., \& Eden, P. (2001). Ecological impacts of arable intensification in Europe. Journal of Environmental Management, 63(4), 337-365. https://doi.org/10.1006/jema.2001. 0473.

Titus, K., Mosher, J. A., \& Williams, B. K. (1984). Chance-corrected Classification for Use in Discriminant Analysis: Ecological Applications. The American Midland Naturalist, 111(1), 1-7. https://doi.org/10.2307/2425535.

van Asselen, S., \& Verburg, P. H. (2012). A Land System representation for global assessments and land-use modeling. Global Change Biology, 18(10), 3125-3148. https:// doi.org/10.1111/j.1365-2486.2012.02759.x.

van de Steeg, J. A., Verburg, P. H., Baltenweck, I., \& Staal, S. J. (2010). Characterization of the spatial distribution of farming systems in the Kenyan Highlands. Applied Geography, 30(2), 239-253. https://doi.org/10.1016/j.apgeog.2009.05.005.

van der Zanden, E. H. (2016). Agricultural landscapes in Europe: spatial structure, land management and consequences of agricultural abandonment.

Venables, W. N., \& Ripley, B. D. (2002). Modern Applied Statistics with S. New York: Springer (Fourth).

Wei, T., \& Simko, V. (2017). R package "corrplot": Visualization of a Correlation Matrix (Version 0.84). Retrieved from https://github.com/taiyun/corrplot.

Weihs, C., Ligges, U., Luebke, K., \& Raabe, N. (2005). klaR Analyzing German Business Cycles. In D. Baier, R. Decker, \& L. Schmidt-Thieme (Eds.), Data Analysis and Decision Support. (pp. 335-343). Berlin: Springer-Verlag. 